Review Article

\title{
Liver-derived Extracellular Vesicles: a Cell by Cell Overview to Isolation and Characterization Practices
}

Cristina Zivko, ${ }^{1,2}$ Gregor Fuhrmann, ${ }^{\star 2}$ Paola Luciani*

${ }^{1}$ Department of Chemistry and Biochemistry, University of Bern, Switzerland

${ }^{2}$ Helmholtz-Institute for Pharmaceutical Research Saarland (HIPS), Saarland University, Germany

${ }^{*}$ Corresponding authors

E-Mail addresses:

gregor.fuhrmann@helmholtz-hzi.de (G. Fuhrmann), paola.luciani@dcb.unibe.ch (P.Luciani) 


\section{Abstract}

BACKGROUND: Extracellular vesicles (EVs) are a diverse group of membrane-bound nanovesicles potentially released by every cell. With the liver's unique ensemble of cells and its fundamental physiological tasks, elucidating the role of EV-mediated hepatic cellular crosstalk and their role in different pathologies has been gaining the attention of many scientists.

SCOPE OF REVIEW: The present review shifts the perspective into practice: we aim to critically discuss the methods used to purify and to biochemically analyse EVs from specific liver resident cells, including hepatocytes, hepatic stellate cells, cholangiocytes, liver sinusoidal endothelial cells, Kupffer cells, liver stem cells. The review offers a reference guide to current approaches.

MAJOR CONCLUSIONS: Strategies for EV isolation and characterization are as varied as the research groups performing them. We present main advantages and disadvantages for the methods, highlighting common causes for concern, such as FBS handling, reporting of cell viability, EV yield and storage, differences in differential centrifugations, suboptimal method descriptions, and method transferability. We both looked at how adaptable the research between human and rodent cells in vitro is, and also assessed how well either of them translates to ex vivo settings.

GENERAL SIGNIFICANCE: We reviewed methodological practices for the isolation and analysis of liver-derived EVs, making a cell type specific user guide that shows where to start, what has worked so far and to what extent. We critically discussed room for improvement, placing a particular focus on working towards a potential standardization of methods. 


\section{Introduction}

Extracellular vesicles (EVs) is a collective term referring to a diverse group of small membrane vesicles virtually released by all cell types, and which are generally being categorized according to their biogenesis:[1,2] apoptotic bodies are blebs of the dying cell membrane and have the broadest size range; microvesicles, sometimes referred to as microparticles or ectosomes, stem from the outward budding of the cellular membrane. Exosomes, which tend to be the smallest subpopulation, are released into the extracellular space after multivesicular bodies (MVB) fuse with the cell membrane (Figure 1). It is still not really possible to isolate one subpopulation from the others, and while it is believed that they may display biomolecules that are enriched to different extents, their overlapping composition, density and size, as well as the absence of subtype-specific markers still make for a considerable challenge.[3,4] The recent discovery of their role in intercellular communication captivated the attention of a growing number of scientists anticipating the enormous potential of EVs in the fields of diagnostics and drug delivery.[5,6] For some pathological dispositions EVs can be applied as liquid biopsies, and that has sparked a lot of interest from a diagnostic perspective. EVs are enriched in selected biomolecules, they are intrinsically equipped to protect their cargo from degradation, and while their complexity offers many characterization opportunities (see Figure 1), they are still simpler to analyse than total blood or serum samples. The interest in EVs as drug delivery systems stems from their potential advantages over synthetic carriers: they are bioavailable, biocompatible, resistant to RNAases and proteases (high physicochemical stability), capable of long-distance communication and they are intrinsically able to interact with cells even across species.[7-9]

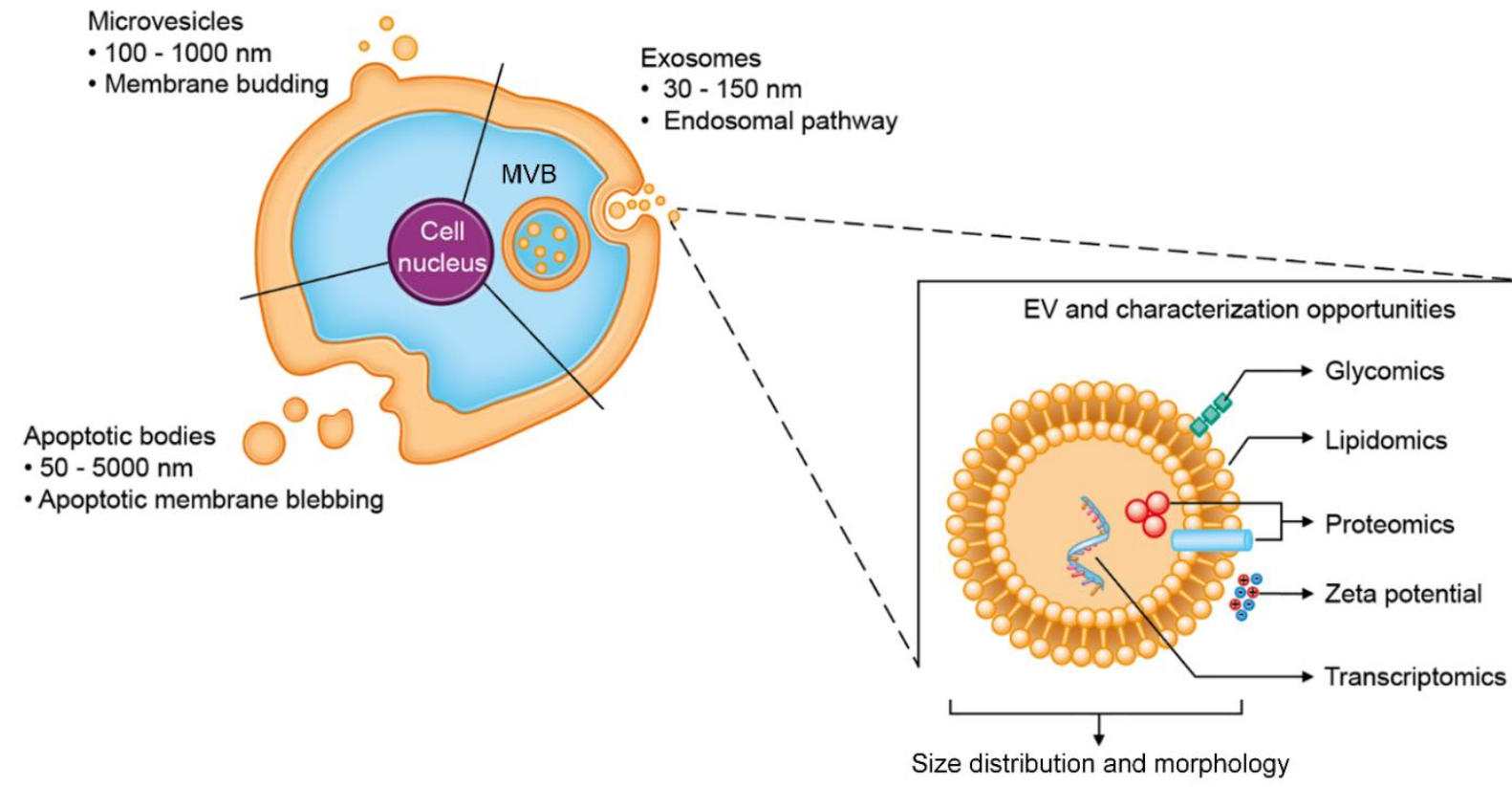

Figure 1: EV nomenclature according to biogenesis; zoomed insert shows a schematic representation of a single EV with characterization opportunities. 
The increasing scientific interest in EVs[10] has led to the establishment of dedicated, open access databases such as Vesiclepedia,[11] EVpedia[12] and EV-TRACK,[13] which are being regularly updated. The majority of the information is concerning proteins, whereas EV-TRACK sets itself apart by focusing on method transparency.

As reviewed elsewhere,[14,15] there are significant challenges (small yields, co-purification of contaminants, etc.) in finding the most efficient protocols for the isolation and sufficient characterization of EVs. We will discuss them in an effort to encourage sharing the current knowledge of the more practical scientific trends in those areas, starting with the present review on liver-derived EVs.

The liver is a large and complex organ responsible for a variety of essential physiological tasks including protein synthesis, lipid storage regulation, xenobiotic detoxification, and offering support to both immunological activity and food digestion.[16] It is difficult to understate its importance. When organ function is compromised, hepatic diseases are directly responsible for as many as 2 million deaths per year: liver cirrhosis alone kills 1.16 million people every year, and hepatocellular carcinoma accounts for the death of $788^{\prime} 000$ more, meaning that combined they cause $3.5 \%$ of all yearly deaths in the world. $[17,18]$ The global health burden of liver associated conditions is not sufficiently addressed as of yet.[19] With its unique ensemble of diverse cells (see Figure 2), the liver offers the opportunity to study intra- and inter-cellular communication. Elucidating the role of EV-mediated hepatic cellular crosstalk has gained the attention of many researchers, who have been able to review its critical role in both health and disease, pointing to differences in the set of EVs that are released, especially in the case of tumors.[20-25] 


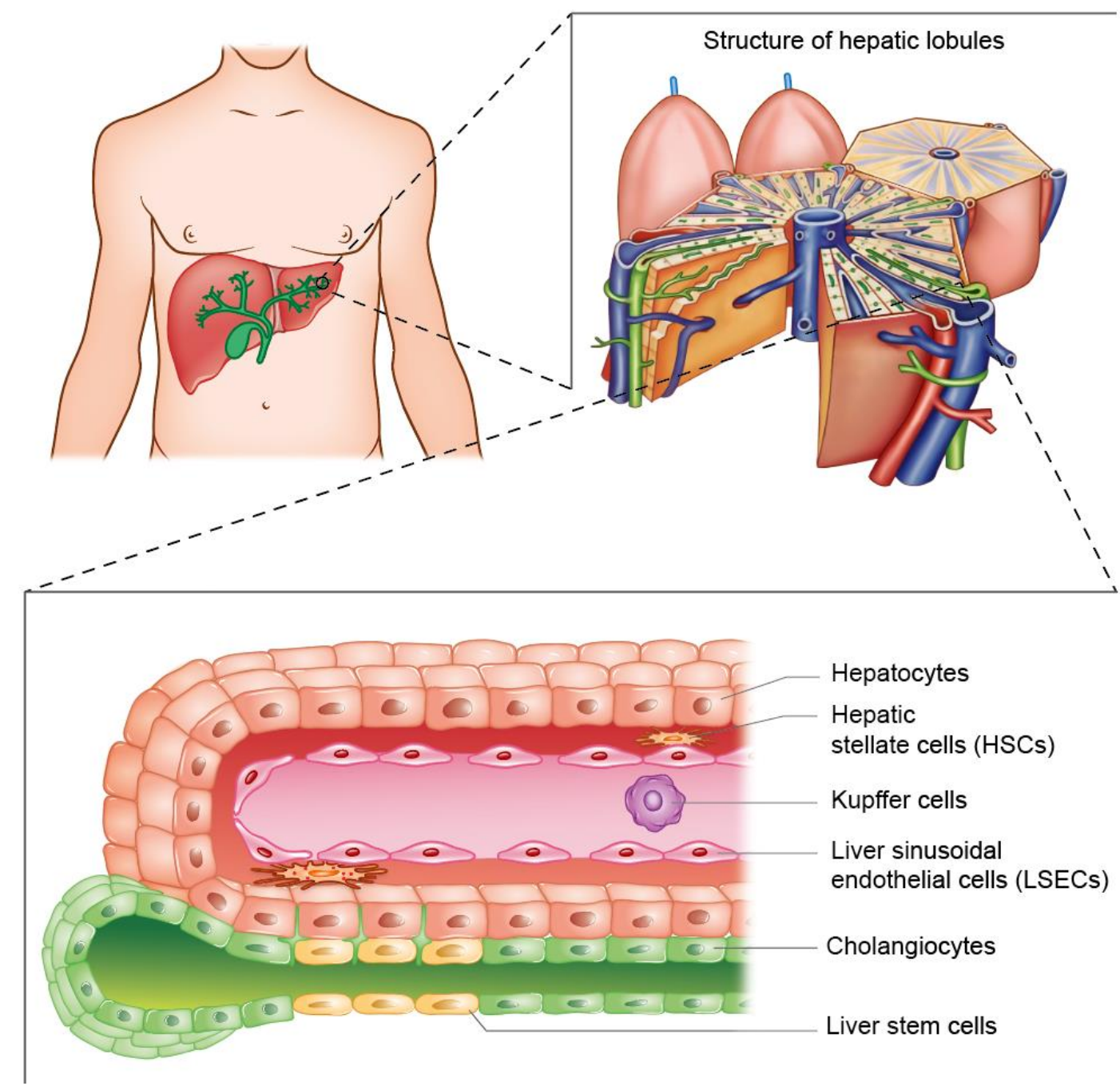

Figure 2: Liver location, structure of hepatic lobules (adapted with permission[26]) and their anatomy at the cellular level: hepatocytes (the most abundant cells in the liver and responsible for the most tasks, see chapter 2), hepatic stellate cells (vitamin A storing cells, chapter 3 ), cholangiocytes (modifying the bile along the bile ducts, chapter 4), liver sinusoidal endothelial cells (lining the fenestrated layer of blood vessels, chapter 5), Kupffer cells (liver resident macrophages, chapter 6), liver stem cells (potentially playing a role in liver regeneration, chapter 7 ).

The present review shifts the perspective into practice: we aim to critically consider the methods used to purify and to biochemically analyse EVs from specific cells, offering a user/reference guide to current practices (see Table 1). The most common and (when applicable) the most original/promising protocols will be examined in order to provide a discussion frame. Diving into the different methodological approaches, we will also highlight limitations and possible inconsistencies. Finally, the (interspecies) method transferability and the translational applicability of these practices will be examined. We will look within the individual cell specific chapters if the same or similar methods could be transferred to different in vitro systems (rodent cells, co-cultures), but we will also explore the practical strategies for EVisolation and characterization that were applied ex vivo and in the clinic from patients with liver-related conditions (chapter 8). It is worth noting, that we are only covering method employment and it is not our role to comment on the quality of the results gained from them. As to the nomenclature, we strived to keep it as it was applied in the referenced manuscripts, only changing it to "EVs" if we needed to paraphrase, since it is the preferred generic term.[1,2] 
Table 1: Overview of the methods for liver-derived EVs.

\begin{tabular}{|c|c|c|c|c|c|c|c|}
\hline \multicolumn{2}{|c|}{ Related Chapter } & EV origin & FBS handling & Isolation techniques & Yield & Storage & $\begin{array}{c}\text { Analysis/ } \\
\text { Characterization }\end{array}$ \\
\hline \multicolumn{8}{|c|}{ [In vitro/Cell culture] } \\
\hline \multirow[t]{2}{*}{2} & h-Hepatocytes & $\begin{array}{l}\text { Hep3B,[27-35] } \\
\text { HepG2,[27-33,36-50] } \\
\text { PLC/PRF/5,[28,29,40,51] } \\
\text { 97H,[35,52] } \\
\text { LM3,[35,38,52,53] } \\
\text { Huh6,[27] } \\
\text { Huh7,a) } \\
\text { Huh-7.5,[54,55] } \\
\text { Bel-7402,[50] } \\
\text { Q64-7703,[37] } \\
\text { MH CC92-H,[37] } \\
\text { LO2,[37,52] } \\
\text { LSQT-2,[38] } \\
\text { MHCC97L,[38] } \\
\text { SMMO7721,[38] } \\
\text { HKCl-C3,[56] } \\
\text { HKCI-B [56] }\end{array}$ & $\begin{array}{l}\text { UC-dep, },{ }^{\text {b) }} \\
\text { ExoFree- } \\
\text { FBS,[36,57] } \\
\text { SSt }(12,24,72 \\
\text { h) }{ }^{\text {c) }}\end{array}$ & $\begin{array}{l}\text { dUc, }{ }^{\text {d) }} \\
\text { filtration, }^{\text {e) }} \\
\left.\text { ExoQuick }^{\mathrm{TM}}, \mathrm{f}\right) \\
\text { Total Exosome } \\
\text { Isolation }^{\mathrm{TM}}(\mathrm{TEI}),[43,53] \\
\text { density gradient } \mathrm{UC}, \mathrm{g}) \\
\text { sucrose cushion } \\
\text { UC[30,58] }\end{array}$ & $\begin{array}{l}\text { protein } \\
\text { content,[28,43,59,60] } \\
\text { relative particle } \\
\text { number,h) } \\
\text { particle number per } \\
\text { number of cells,[35,56] } \\
\text { molar } \\
\text { concentration[27] }\end{array}$ & $\begin{array}{l}\text { at } 4^{\circ} \mathrm{C} \text { for no longer } \\
\text { than } 48 \mathrm{~h},[30] \\
\text { at }-70^{\circ} \mathrm{C},[39] \\
\left.\text { at }-80^{\circ} \mathrm{C}, i\right) \\
\text { dried EV-pellet at }-80 \\
{ }^{\circ} \mathrm{C}[27]\end{array}$ & $\begin{array}{l}\text { TEM, }{ }^{\mathrm{j})} \\
\text { immunogold TEM, } \\
\text { flow cytometry, } \\
\text { western blot, }{ }^{\mathrm{m})} \\
\text { NTA, } \\
\text { AFM },[27] \\
\text { DLS, }{ }^{\circ)} \\
\text { BCA assay, }{ }^{\mathrm{p})} \\
\text { Bradford } \\
\text { assay,[33,43,56-58] } \\
\left.\text { RNA, }{ }^{9}\right) \\
\text { proteomics,[32,35] } \\
\text { custom colorimetric } \\
\text { nanoplasmonic assay } \\
\text { (molar } \\
\text { concentration)[27] }\end{array}$ \\
\hline & r-Hepatocytes & $\begin{array}{l}\text { primary rat } \\
\text { hepatocytes,[32,41,61] } \\
\text { primary mouse } \\
\text { hepatocytes,[62-66] } \\
\text { Hca-F,[67] } \\
\text { Hca-P,[67] } \\
\text { H22,[68] } \\
\text { IMH[69] }\end{array}$ & $n / f$ & $\begin{array}{l}\text { dUc, } \\
\text { density gradient UC } \\
\text { filtration }\end{array}$ & $\begin{array}{l}\text { protein content, } \\
\text { relative particle } \\
\text { number, } \\
\text { particle number per } \\
\text { number of cells }\end{array}$ & $n / f$ & $\begin{array}{l}\text { TEM, } \\
\text { DLS, } \\
\text { zeta potential, } \\
\text { western blot, } \\
\text { fluorescence } \\
\text { microscopy, qRT- } \\
\text { PCR, } \\
\text { proteomics, } \\
\text { flow cytometry } \\
\text { NTA }\end{array}$ \\
\hline \multirow[t]{2}{*}{3} & h-HSCs & LX-2[70-73] & $\begin{array}{l}\text { SSt }(16,48 \\
\text { h),[71-73] } \\
\text { ExoFree- } \\
\text { FBS[70] }\end{array}$ & $\begin{array}{l}\text { dUc,[72,73] } \\
\text { ExoQuick }^{\text {TM }}[70]\end{array}$ & $\begin{array}{l}\text { relative particle } \\
\text { number[73] }\end{array}$ & $n / f$ & $\begin{array}{l}\text { NTA,[73] } \\
\text { DLS,[72] } \\
\text { zeta potential, [72] } \\
\text { RNA, [70] } \\
\text { TEM,[71-73] } \\
\text { western blot[72,73] }\end{array}$ \\
\hline & r-HSCs & $\begin{array}{l}\text { primary rat HSCs,[74] } \\
\text { primary mouse } \\
\text { HSCs,[72,75-77] }\end{array}$ & $\begin{array}{l}\text { UC-dep,[76] } \\
\text { SSt }(16,48 \\
\text { h)[74] }\end{array}$ & $\begin{array}{l}\text { dUc,r) } \\
\text { density gradient } \\
\text { UC,[20,74] } \\
\text { TEI[77] }\end{array}$ & $\begin{array}{l}\text { relative particle } \\
\text { number[}[75,76]\end{array}$ & $\begin{array}{l}\text { at } 4^{\circ} \mathrm{C} \text { and used } \\
\text { within } 72 \mathrm{~h}[74]\end{array}$ & $\begin{array}{l}\text { TEM,[20,72,74-76] } \\
\text { DLS,[20,72] } \\
\text { zeta potential,[72] }\end{array}$ \\
\hline
\end{tabular}




\begin{tabular}{|c|c|c|c|c|c|c|c|}
\hline & & $\begin{array}{l}\text { rat HSC-derived } \\
\text { PMF[20] }\end{array}$ & & & & & $\begin{array}{l}\text { western } \\
\text { blot,[20,72,75,77] } \\
\text { fluorescence } \\
\text { microscopy[76] } \\
\text { qRT-PCR,[77] } \\
\text { proteomics,[20,74,78] } \\
\text { flow cytometry,[20] } \\
\text { RNA[74] }\end{array}$ \\
\hline \multirow[b]{2}{*}{4} & h-Cholangiocytes & $\begin{array}{l}\text { EGI1,[79] } \\
\text { TFK-1,[79] } \\
\text { H69[80] }\end{array}$ & $\begin{array}{l}\text { UC-dep,[80] } \\
\text { SSt (48 h)[79] }\end{array}$ & $\begin{array}{l}\text { dUc, }[79][80] \\
\text { filtration[79] }\end{array}$ & $\begin{array}{l}\text { relative particle } \\
\text { number[79][80] }\end{array}$ & at $-80^{\circ} \mathrm{C}[79]$ & $\begin{array}{l}\text { NTA, }[79] \cdot[80] \\
\text { TEM, }[79],[80] \\
\text { proteomics, }[79] \\
\text { western blot[79] }\end{array}$ \\
\hline & r-Cholangiocytes & $\begin{array}{l}603 \mathrm{~B},[74] \\
\text { primary mice } \\
\text { cholangiocytes[81] }\end{array}$ & $\begin{array}{l}\text { UC-dep,[81] } \\
\text { SSt }(16 \text { h)[74] }\end{array}$ & $\begin{array}{l}\text { dUc[74] } \\
\text { density gradient UC[74] }\end{array}$ & $n / f$ & $n / f$ & $\begin{array}{l}\text { TEM, [74][81] } \\
\text { RNA[74] } \\
\text { Protein analysis[74] } \\
\text { DLS,[81] } \\
\text { RNA[81] } \\
\end{array}$ \\
\hline \multirow[t]{2}{*}{5} & h-LSECS & TMNK-1[82] & $n / f$ & $\begin{array}{l}\text { ExoQuick, [82] } \\
\text { dUc[83] }\end{array}$ & $\begin{array}{l}\text { protein content } \\
{[82],[83]}\end{array}$ & $n / f$ & $\begin{array}{l}\text { flow cytometry, [82] } \\
\text { TEM, [83] } \\
\text { immunoblot, [83] } \\
\text { Bradford assay, [83] } \\
\text { BCA assay, [82] } \\
\text { RNA[83] }\end{array}$ \\
\hline & r-LSECs & TSEC[84] & $\begin{array}{l}\text { UC-dep then } \\
20 \% \text { FBS } \\
\text { medium sterile } \\
\text { filtration[84] }\end{array}$ & $n / f$ & $\begin{array}{l}\text { relative particle } \\
\text { number, [84] } \\
\text { protein content[84] }\end{array}$ & $n / f$ & $\begin{array}{l}\text { NTA, [84] } \\
\text { western blot, [84] } \\
\text { TEM,[84] } \\
\text { Bradford assay[84] }\end{array}$ \\
\hline \multirow{2}{*}{6} & h-Kupffer Cells & $\begin{array}{l}\text { THP-1,[83,85,86] } \\
\text { monocyte-derived } \\
\text { macrophages[87] }\end{array}$ & $\begin{array}{l}\text { ExoFree- } \\
\text { FBS[87] }\end{array}$ & $\begin{array}{l}\text { dUc, }[84,85] \\
\text { filtration,[85] } \\
\text { ExoQuick, } \\
\text { TEI[87] }\end{array}$ & $\begin{array}{l}\text { relative particle } \\
\text { number,[85] } \\
\text { protein content[84] }\end{array}$ & $n / f$ & $\begin{array}{l}\text { NTA,[85] } \\
\text { EM, [84,[87] } \\
\text { western blot, [84,[87] } \\
\text { Bradford assay,[84] } \\
\text { RNA[84] }\end{array}$ \\
\hline & r-Kupffer Cells & $\begin{array}{l}\text { mice hepatic } \\
\text { macrophages[36,65,66] }\end{array}$ & UC-dep[35] & $\begin{array}{l}\text { dUc, }[35,64,65] \\
\text { sucrose gradient }[64,65]\end{array}$ & $\begin{array}{l}\text { relative particle } \\
\text { number[64,65] }\end{array}$ & $n / f$ & $\begin{array}{l}\text { NTA[64,65] } \\
\text { flow cytometry,[35] } \\
\text { DLS,[35] } \\
\text { TEM,[35] } \\
\text { RNA[35] }\end{array}$ \\
\hline 7 & h-Liver Stem Cells & HLSCs[88-97] $]^{3}$ & $\begin{array}{l}\text { SSt }(24 \mathrm{~h})[163- \\
173]\end{array}$ & $\begin{array}{l}\text { dUc,[163-173] } \\
\text { custom charge-based } \\
\text { precipitation method, [98] } \\
\text { size exclusion } \\
\text { chromatography[97] }\end{array}$ & $\begin{array}{l}\text { relative particle } \\
\text { number[163-173] }\end{array}$ & $\begin{array}{l}\text { at }-80^{\circ} \mathrm{C} \text { with } 5 \%(\mathrm{v} / \mathrm{v}) \\
\text { DMSO[88-97] }\end{array}$ & $\begin{array}{l}\text { NTA, [88-97] } \\
\text { TEM, [88-97] } \\
\text { western blot, [88-97] } \\
\text { RNA, [88-97] } \\
\text { Raman } \\
\text { spectroscopy,[97] }\end{array}$ \\
\hline
\end{tabular}




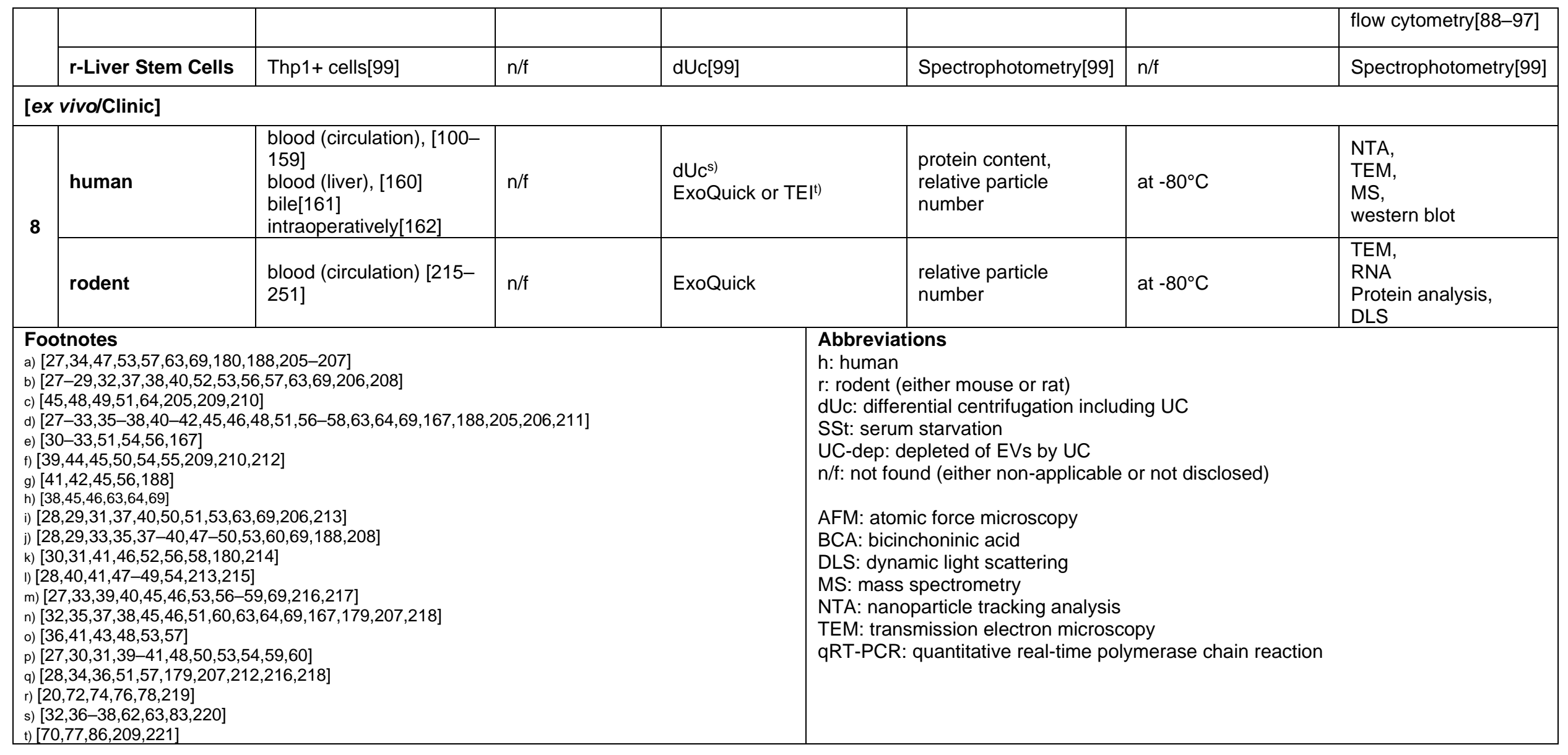




\section{EVs from Hepatocytes}

Hepatocytes are the most abundant cells in the liver, comprising about $70-80 \%$ of its mass, they are dedicated to protein synthesis (serum albumin, transferrin and other glycoproteins), while also being the main site for glycolysis and only site for bile salts production in the body.[222-224] Another essential task relying on hepatocytes is detoxification: they metabolize both exogenous (e.g., drugs, toxins) and endogenous (e.g., steroids) compounds.[225,226] More notable still is their ability to regenerate the injured liver.[227] Given their prominent presence, their multifaceted roles, and their direct association to many liver diseases (fatty liver, chronic hepatitis, non-alcoholic fatty liver disease, non-alcoholic steatohepatitis, liver fibrosis, hepatocellular carcinoma),[228] it is not surprising that they have been the most frequent focus of research involving liver-derived EVs so far.

\subsection{Isolation strategies}

EVs have been isolated from both cryopreserved primary hepatocytes[54,60,179,212] as well as from cell lines (see Table 1).

Berardocco et al. 2017[27] isolated EVs from Hep3B, HepG2, Huh7 and HuH6 human hepatocarcinoma (HCC) cell lines by differential centrifugation: first cells were removed ( $300 \times \mathrm{g}, 10 \mathrm{~min}$ ), then apoptotic bodies (2'000 x g, $30 \mathrm{~min}$ ), and finally cell organelles (16'000 x g, $20 \mathrm{~min}$ ). EVs were then pelleted by ultracentrifugation (UC; $120^{\prime} 000 \mathrm{xg}$ for $70 \mathrm{~min}$ ) and the EV-enriched pellet was resuspended in PBS and purified by repeating the UC step. Everything was performed at $4{ }^{\circ} \mathrm{C}$, and the final EV-pellet was drained, rapidly frozen in liquid nitrogen and stored at $-80^{\circ} \mathrm{C}$ before analysis. Cells were grown in cell culture medium supplied with $10 \% \mathrm{FBS}$, but EVs were isolated after having it exchanged with medium containing $1 \%$ FBS and $0.25 \%$ human serum albumin (hBSA), both of which had been previously depleted of EVs by UC (120'000 $x \mathrm{~g}$ for $5 \mathrm{~h}$ ). We appreciated the care that was taken to depleting FBS and hBSA of EVs prior to use; experimental corroboration on the chosen protocol was missing, yet it has been previously reported that even $18 \mathrm{~h}$ long UC is not necessarily effective to remove all FBSEVs.[229]

As to the isolation of the hepatocyte derived EVs themselves, other groups worked similarly, but preferred different centrifugation times and forces (e.g. Cannito et al. 2017:[48] 3'000 x g for 15 min, then $\mathrm{UC}$ at $100^{\prime} 000 \mathrm{x}$ for 90 minutes at $10^{\circ} \mathrm{C}$ ). Why some numbers were chosen over others is rarely explicitly justified: sometimes it is disclosed that previously reported methods have been adopted (e.g. Fang T. et al. 2018[38] citing Lässer et al. 2012[230]), and oftentimes published practices were adapted without explaining what prompted the tweak. A direct experimental validation could not always be found, which is a major weakness of these protocols.

He et al. 2015[56] added a filtration step $(0.22 \mu \mathrm{m})$ that followed their differential centrifugation $(500 \mathrm{x} \mathrm{g}$ for $10 \mathrm{~min}$, then $16^{\prime} 500 \mathrm{xg}$ for $30 \mathrm{~min}$ ) and preceded the UC (110'000 x g, $\left.70 \mathrm{~min}\right)$. After this, the EVpellet was washed and purified in PBS by performing a UC step on a $40 \%(\mathrm{w} / \mathrm{v})$ sucrose cushion, which 
was followed by yet another UC wash in PBS. The protocol seemed to address the concern that UC can lead to co-isolation of other impurities (protein aggregates, lipoproteins) more carefully.

Others avoided UC by favoring commercially available precipitation kits such as ExoQuick ${ }^{\mathrm{TM}}[50,54,216]$ and Total Exosome Isolation ${ }^{\mathrm{TM}}$ (TEI).[43,58] These kits have been suggested to be more easily translated into clinical settings because not every hospital has an ultracentrifuge, the required accessories, and the specifically trained personnel, and they occasionally yield more and even more pure EVs,[231] although there are still conflicting reports about it.[232,233]However, they come with their own set of perplexities: different precipitation kits are commercially available, but their composition being proprietary information makes it hard to evaluate their efficacy in excluding contaminants and in their ability to work with EVs from any cell type.

Yet another approach was to opt for membrane affinity spin columns such as ExoEasy Maxi ${ }^{\mathrm{TM}}$, opted by Cao et al. 2019.[167]

It is worth pointing out that the storage strategy is not always disclosed, let alone the validation thereof. Similar to Berardocco et al. 2017, EV pellets were stored at $-80{ }^{\circ} \mathrm{C}$ by other groups too,[28,29,31,37,40,50,51,53,63,69,206,213] mostly after re-suspending them in PBS (when the final volume is shared, it tends to be between 50 and $500 \mu \mathrm{L}$ ), or at $-70{ }^{\circ} \mathrm{C}$.[39] We particularly appreciated the caution of Xiao et al. 2010,[30] who stored EVs at $4{ }^{\circ} \mathrm{C}$ for no longer than $48 \mathrm{~h}$ before use.

\subsection{Characterization}

When evaluating the quality of the isolation methods, we would like to point to the approach of Thacker et al. 2018,[45] who tested different protocols, directly comparing them to UC: ExoQuick ${ }^{\mathrm{TM}}$ was shown to lead to the highest co-purification of extravesicular contaminants, while OptiPrep ${ }^{\mathrm{TM}}$ yields were deemed too low. They describe culturing HepG2 in T75 flasks, 2.1 million cells $/ \mathrm{mL}$ in $10 \mathrm{~mL}$ at seeding, and harvesting EVs after 2-3 days, starting from $4 \mathrm{~mL}$ of cell culture medium and calculating back the number of particles $/ \mathrm{mL}$ for yield comparisons $\left(10^{11} \mathrm{p} / \mathrm{mL}\right.$ by ExoQuick ${ }^{\mathrm{TM}}, 10^{10} \mathrm{p} / \mathrm{mL}$ by UC). It would have been beneficial to report the number of cells and their viability at the time of medium collection to use the method performances for future comparisons of protocol efficiency, not only efficacy. This would allow to find whether EVs can be isolated by a certain approach, but also to evaluate how many EVs can be retrieved from a specific number of cells, and how viable the cells were at the time of EV collection to minimize concerns about isolation of apoptotic bodies. Tentative quantification by other groups, when reported, was sometimes shown as relative release after measuring concentration by nanoparticle tracking analysis (NTA),[46,63,234] better still by normalizing it to cell number.[56,210] Others favoured protein quantification[31,37,43] (even normalizing it to a number of cells[60]), or counting EVs as seen by EM.[52] Little attention was given to explicitly stating the cell viability; exceptions include Eguchi et al. 2017,[36] reporting on 90.5 - 94.5\% cell viability, and Xiao et al. 2010[30] documenting 95\%.

The intrinsic uncertainty associated with isolation and purification techniques makes the characterization steps all the more important. We found Berardocco et al. 2017,[27] again to be thorough in their approach using gel electrophoresis for protein profiling, atomic force microscopy (AFM) for morphology and size, and a previously developed colorimetric nanoplasmonic assays (see Maiolo et al. 2015[235]) to evaluate EV-purity and concentration. Protein content determination was performed by bicinchoninic 
acid (BCA) assay and western blot analysis was done for EV and non-EV markers (GM130, calnexin, Hsp70, CD63, CD9, TGM2, EpCAM, E-cadherin, LGR5 and $\beta$-actin). Total RNA from EVs was purified using the Fatty Tissue RNA Purification kit, SOLiD Library preparation, sequencing and bioinformatic analysis was done by GENOMNIA.

Other groups have favoured dynamic light scattering (DLS) for EV-size determination,[36,48,57] tuneable resistive pulse sensing (TRPS, i.e. qNano $^{\mathrm{TM}}$ ),[56] nanoparticle tracking analysis (NTA; for size and concentration),[37,38,49] transmission electron microscopy (TEM)[28,29,33,35,37-40,47$50,53,60,69,188,208$ ] (sometimes combined to immunogold staining of EV markers), $[30,31,41,46,52,56,58,180,214]$ or cryo-TEM (for size and morphology)[187,193,194,236] and even scanning EM (SEM).[43] Quantification and marker expression analysis of EVs by flow cytometry was also done[28,40,41,47-49,54,213,215] (e.g. Cobb et al. 2018,[54] using a kit for exosome immunocapture and colorimetric quantification). Proteomic analysis on hepatocyte-derived EVs was performed to various degrees by several groups, we will only mention a few; $[35,61,174]$ the same applies to total and specific RNA evaluations.[36,51,52,216] Lipidomics characterization was found in the study by Kakazu et al. 2016,[69] who looked at ceramides and non-esterified Fas (cell surface death receptor) by mass spectrometry (MS). Finally, Wu et al. 2018[60] reported an EV zeta potential between -20 and $-30 \mathrm{mV}$.

\subsection{Interspecies method transferability}

Different groups have retrieved hepatocyte-EVs originating from mice and rats and we would like to highlight those providing comparison to human cells.

Povero et al. 2013[41] compared HepG2 to rat-derived hepatocyte-EV, isolating them by differential centrifugation (including UC) and, for selected experiment, further purified them by 10 to $70 \%$ sucrose gradient UC (150'000 x g, $\left.18 \mathrm{~h}, 10^{\circ} \mathrm{C}\right)$. Eguchi et al. 2017[36] had isolated by UC EVs from HepG2 and from primary mice hepatocytes, as well as blood-EVs from mice plasma. A few researchers used the Huh7 cell line, again looking at EVs released from mice hepatocytes after isolating them by UC. $[63,69,180]$ When looking at increasing the complexity of the analyzed system without going in vivo still, we would like to single out Dioufa et al. 2017,[237] for using their own ex vivo human liver microphysiological system (MPS), developed with primary hepatocytes and non-parenchymal cells (NPCs) from the liver. EVs from the liver MPS were isolated by polymeric precipitation with the TEI kit, and they were then analyzed by TEM and for total RNA, as well as for CDNA and miRNA; exosomes markers were evaluated by western blot using the Exo-Check ${ }^{\mathrm{TM}}$ exosome antibody array). More interesting still, some managed to compare human hepatocytes cell lines to primary rodents cells as well as samples obtained from human donors within the same study (see chapter 8).[32,62,63]

\section{EVs from Hepatic Stellate Cells}


Hepatic stellate cells reside in the space of Disse (Figure 2), between hepatocytes and endothelial cells, and are mainly responsible for storing vitamin A in cytoplasmic lipid droplets.[238] Upon liver injury, however, they undergo transdifferentiation into a myofibroblast-like state, i.e., they become activated, progressively lose their lipid droplets and start promoting fibrogenesis, most notably by deposition of excessive and collagen rich extracellular matrix.[239,240] When the injuries are repeated during chronic diseases and the fibrosis is not resolved, the excessive deposition of scar tissue eventually leads to cirrhosis and the loss of organ function. The pivotal role of HSCs in liver fibrosis makes these cells crucial therapeutic and diagnostic targets.[241]

\subsection{Isolation strategies}

For the in vitro isolation of HSC-derived EVs, a common cell line seems to be the LX-2, which has the advantage of being able to grow under serum free conditions.[242]

Brandon-Warner et al. 2016[70] isolated EVs from cell culture medium using the ExoQuick ${ }^{\text {TM }}$ precipitation kit, after culturing the cells with $10 \%$ of commercially available Exo-free FBS. Information about cell number and viability at the time of EV-collection and the total yield are missing, making it hard to judge the efficiency of their method. Purification steps after this were not performed and it is not specified how EVs were stored between isolation and analysis.

Serial centrifugation was the preferred method for Chen L. et al. 2014, Charrier et al. 2014 and Wang et al. 2018.[71,72,243] Cell culture medium for EV-isolation had been prepared without FBS, and the LX-2 cells were serum-starved for 48-72 h but a measure of cell number, density and viability is unfortunately missing. The specific isolation protocols were found inconsistent, because Charrier et al. 2014 refer their readers to Chen L. et al. 2014, which in turn cite Thery et al. 2006,[244] an overview of different protocols for the isolation of EVs. While the projects described in these articles were not focusing on the EVs isolated from HSCs, more descriptive protocols would better facilitate reproducibility. Wang et al. 2018[243] adapted an "exosome" isolation procedure based on cholangiocytes and previously reported in Li L. 2016,[245]. Unfortunately, Li et al. refer to yet another isolation protocol (Li L. et al. 2014,[155] see chapter 8) which makes it challenging to compare them.

\subsection{Characterization}

Brandon-Warner et al. 2016[70] investigated total RNA, which was isolated using the SeraMiR ${ }^{\mathrm{TM}}$ exosome RNA purification kit, then quantified and analysed it to compare differences in the expression levels of individual miRNAs in cells and exosomes.

Charrier et al. 2014[71] characterized their isolated EVs by electron microscopy, expression of key markers and size, based on protocols from Thery et al. 2011[246] and Chen et al. 2014.[72] The latter explains their characterization steps for HSC-EVs isolated from mice, adding that "similar procedures" were used for EVs originating from LX-2 cells. They performed western blots (CD9), TEM, DLS analysis, zeta potential measurements, and analysed exosomal and cellular RNAs for the presence of miR-21, which was determined by real time polymerase chain reaction (RT-PCR). 
While not as frequently explored as hepatocyte-derived EVs (see chapter 2), HSC-EVs have been analysed by a diverse array of means. Reporting of the protocols frequently relied on additional references to be looked up across different papers, which can complicate the ease with which reported methods could be reproduced.

\subsection{Interspecies method transferability}

There are even more examples for research involving murine and rat HSC-derived EVs than their human counterpart. In Chen L. et al. 2015,[78] Chen L. and Brigstock 2016[76] and Chen L. et al. 2016[75] EVs were purified as described in Chen L. et al. 2014[72] (differential centrifugation and UC, referring the reader to Thery et al. 2006[244]) from primary mice cells. EVs were analysed by NTA, and imaged by cryo-TEM. Exosomal mRNA was determined by quantitative RT-PCR, while cellular EV-uptake was observed by confocal microscopy (EVs were stained with PKH26). Exosomal proteins were evaluated by western blot. Within this study (Chen et al. 2014), they also looked at circulating EVs but changed their isolation method. EVs were harvested from murine sera using PureExo Exosome Isolation Kits. Total exosomal RNA from sera was prepared using miRNeasy mini kits.

Povero et al. 2014[20] and Witek et al. 2009[74] used primary rat HSCs: the former opted for differential centrifugation (including UC, as applied to HepG2, see chapter 2), while the latter preferred polymeric precipitation (TEI). Lambrecht et al. 2017[77] evaluated EVs from mice HSCs and those found in human plasma (see chapter 8).

A rigorous parallelization of isolation and characterization practices is missing, but research with HSCderived EVs has been steadily gaining attraction, and their biochemical properties as analysed from rodent models are being increasingly explored in more complex settings.

\section{EVs from Cholangiocytes}

Cholangiocytes are epithelial cells lining the bile ducts (Figure 2), which can differ in size and morphology just as the bile duct tree itself does. Their main physiological role is the modification of the bile coming from the liver while it is being transported along the biliary ducts into the intestine.[247-250] Pathologies directly associated with cholangiocytes include primary biliary cholangitis, and primary sclerosing cholangitis, for which liver transplantation is the only available cure. Primary sclerosing cholangitis also leads to different cancers collectively known as cholangiocarcinoma.[250-252]

\subsection{Isolation strategies}

Cholangiocyte-EVs were preferentially isolated by serial centrifugation followed by UC. Sato et al. 2017[80] used the $\mathrm{H69}$ cell line, cultured with FBS that had been depleted of EVs by UC $(120 \times 000 \times \mathrm{g}$, $18 \mathrm{~h}$ ). For EV isolation, they first removed cell debris ( $300 \times \mathrm{g}$ for $10 \mathrm{~min}$, then 3 '000 $\mathrm{xg}$ for $30 \mathrm{~min}$ ), after which they filtered the supernatants $(0.22 \mu \mathrm{m})$ before $\mathrm{UC}\left(120^{\prime} 000 \times \mathrm{g}, 3 \mathrm{~h}\right)$. EV-pellets were then 
washed with $30 \mathrm{~mL}$ PBS, pelleted again by UC (120'000 x g, $2 \mathrm{~h})$ and re-suspended in $0.5 \mathrm{~mL}$ PBS. The adopted strategy of performing a filtration followed by PBS washes indicates a concern EV-purification. The description of the methods shows an attention to details that enable reproducibility, such as sharing the volume of PBS used to re-suspend the final pellet, which also helps put the yield as shown in the NTA distribution profiles into perspective.

A slightly different approach was found in Arbelaiz et al. 2017,[79] which used the H69, EGI1 and TFK1 cell lines as well as patient blood (see chapter 8 ). Cell culture medium was centrifuged ( $1^{\prime} 500 \times \mathrm{g}, 15$ $\left.\min , 4^{\circ} \mathrm{C}\right)$, the supernatant filtered $(0.22 \mu \mathrm{m})$, and centrifuged again $\left(10^{\prime} 000 \times \mathrm{g}, 30 \mathrm{~min}, 4^{\circ} \mathrm{C}\right)$ before two UC steps $\left(100^{\prime} 000 \times \mathrm{g}, 75 \mathrm{~min}, 4^{\circ} \mathrm{C}\right)$. Samples were store at $-80^{\circ} \mathrm{C}$. It was not possible to extrapolate an absolute yield making comparison of EV-retrieval difficult.

\subsection{Characterization}

To determine the size and concentration of the isolated EVs, NTA and TEM were performed both by Sato et al. 2017 and by Arbelaiz et al. 2017; however, the latter additionally analyzed the EVs' protein profile by mass spectrometry, and evaluated the expression of different EV-markers (CD9, CD63, CD81) by western blot. Research articles about cholangiocyte-derived EVs are more limited in numbers rather than in quality, already providing fruitful isolation protocols and an ample baseline of analytical characterizations to build upon.

\subsection{Interspecies method transferability}

Centrifugation and $\mathrm{UC}$ proved to be a viable strategy for the isolation of EVs from mice cholangiocytes too. Witek et al. 2009[74] performed it when working with the 603B cells, after $16 \mathrm{~h}$ of serum starvation by first removing cells and debris (2'000 x g, $15 \mathrm{~min}$, twice) and then pelleting of EVs by UC (50'000 $\mathrm{x}$ g, $45 \mathrm{~min}$, twice). For selected experiments they would add a purification step by sucrose gradient centrifugation (100'000 x g, $15 \mathrm{~h}$ ). Fresh samples were analyzed for proteomics or they were stored at $4{ }^{\circ} \mathrm{C}$ for no longer than $72 \mathrm{~h}$ before performing TEM and RNA analysis.

Li X et al. 2018[81] worked with murine large and small cholangiocytes (MLEs, MSEs) and they cleared conditioned cell culture medium from cell debris by centrifugation ( $2^{\prime} 000 \mathrm{xg}$ for 15 minutes followed by $16^{\prime} 000 \times \mathrm{g}$ for $20 \mathrm{~min}$, both at $\left.4^{\circ} \mathrm{C}\right)$, and pelleted EVs by UC (100'000 x g, $70 \mathrm{~min}$, at $\left.4^{\circ} \mathrm{C}\right)$. EVs were resuspended in sterile PBS and stored at $-80^{\circ} \mathrm{C}$ for further analysis. EV-size was determined by DLS and confirmed by TEM, and levels of mRNA H19 were assessed. Interestingly, they also isolated EVs from mice (and human) sera too, as further described in chapter 8.

\section{EVs from Liver Sinusoidal Endothelial Cells}

Liver sinusoidal endothelial cells (LSECs) form the fenestrated endothelial layer at the interface between cells in the blood and the HSCs in the space of Disse. LSECs act as efficient pinocytotic scavengers for 
particles that are smaller than $0.2 \mu \mathrm{m}$, making them the central players in clearing the body of bloodborne viruses.[253,254] When working with EVs from LSECs, researchers were interested infections caused by hepatitis $B$ and $C$ viruses (HBV and HCV).

\subsection{Isolation strategies}

EVs were isolated from primary LSECs and from the immortalized TMNK-1 cell line by Giugliano et al. 2015,[82] using the ExoQuick ${ }^{\mathrm{TM}}$ precipitation kit.

Li J et al. 2013[83] preferred serial centrifugations: $300 \times \mathrm{g}$ for $10 \mathrm{~min}, 2^{\prime} 000 \mathrm{x} \mathrm{g}$ for $10 \mathrm{~min}, 10^{\prime} 000 \mathrm{x} \mathrm{g}$ for $30 \mathrm{~min}$; EVs were then pelleted by UC (100'000 $\mathrm{g}$ for $70 \mathrm{~min}$ ), washed in PBS and pelleted by UC again $(100,000 \times \mathrm{g}, 70 \mathrm{~min})$. For selected experiments-sucrose density-gradient centrifugation was performed.

\subsection{Characterization}

The characterization of LSEC-EVs in Giugliano 2015 was limited to the determination of total protein content by BCA and to detection using CD63-labeled Dynabeads. Beadbound EVs were labeled with anti-CD63-PE and anti-CD81-PerCP-eFluor 710 and finally quantified by flow cytometry.

$\mathrm{Li} \mathrm{J}$ et al. 2013 quantified the protein content by Bradford assay, and characterized the EVs by electron microscopy, by immunoblot for exosomal (CD63, TSG101, Alix, LAMP2, $\beta$-actin, Hsp90) and nonexosomal markers (GRP94, EEA1, Cytochrome C), and by microarray analysis of exosomal mRNA and miRNA.

While restricted to a few research articles, EVs from LSECs have been successfully purified and characterized. Follow up research could expand the field by providing more insights into optimized storage strategies or yield determination practices that would allow for comparisons across studies.

\subsection{Interspecies method transferability}

When looking at the protocols applied to studying LSEC-derived EVs from rodents, Wang et al. 2015[255] compared EVs isolated from a mice immortalized LSEC cell line (TSEC[256]) to murine serum-derived exosomes. The description of isolation and purification methods referred the reader to Huebert et al. 2010,[256] Thery et al. 2006,[244] Tu et al. 2015,[257] whose protocols were not related to EVs from LSECs.

LSECs were cultured in medium with $10 \%$ FBS, which was prepared with $20 \%$ FBS first and then depleted of FBS-EVs by UC and sterile filtration. EVs were characterized by NTA, immunogold-EM (CD81, TfR, CD63) and western blot. They also mention using $50 \mu \mathrm{g}$ of exosomes per experiment, as determined by Bradford assay, although an exact number of cells required to achieve such a yield was missing, making it challenging to analytically compare method efficiency across studies. 


\section{EVs from Kupffer Cells}

The resident macrophages in the liver, found in the hepatic sinusoid, are known as Kupffer cells.[258] Since the liver is frequently in contact with exogenous material, suppressing "unwanted" immune responses is essential. Kupffer cells have been shown to provide anti-inflammatory signals that allow homeostatic immunological tolerance under healthy conditions. As part of the innate immune system, these macrophages phagocyte invading pathogens and play a critical role for the initiation of immunological responses when inflammation and recruitment of other cells becomes required by the triggered defence mechanism.[259-261] Dysregulation of these processes is directly connected to pathologies discussed in previous chapters, because Kupffer cells communicate through EVs with hepatocytes, HSCs, Cholangiocytes and LSECs.

\subsection{Isolation strategies}

Aucher et al. 2013[85] chose the THP-1 cells as their model for liver macrophages, collecting their apoptotic bodies and exosomes. The isolation methods was adapted from Hristov et al. 2004[262] with $800 \times \mathrm{g}$ for 10 minutes to remove (endothelial) cells and then pelleting of apoptotic bodies at $16^{\prime} 500 \times \mathrm{g}$ for $20 \mathrm{~min}$. For the isolation of the exosomes it cites the work of Mittelbrunn et al. 2011.[263] The latter stated that donor cells ( $T$ cells) were cultured with 10\% FBS (depleted of bovine EVs by UC at 100'000 x g overnight). Still Mittelbrunn et al. 2011 explain how the conditioned cell culture medium was cleared by centrifugation ( $320 \times \mathrm{g}, 5 \mathrm{~min}$ ); the resulting supernatant was filtered through $0.22 \mu \mathrm{m}$ membranes, and EVs were finally pelleted by UC $\left(100^{\prime} 000 \times \mathrm{g}, 60 \mathrm{~min}, 4^{\circ} \mathrm{C}\right)$. While the methods could be extrapolated, the reliance on references for method description sometimes risks to undercut all the work that was done. Ideally, the methods for EV isolation should also be experimentally validated for every new cell type regardless.

Li J et al. 2013[83] and Saha et al. 2016[86] also used THP-1 cells to model Kupffer cells, as well as primary human monocytes. Saha et al. 2016 (who cultured cells using commercially available ExoFreeFBS $^{\mathrm{TM}}$ ) opted for EV-precipitation with ExoQuick ${ }^{\mathrm{TM}}$, which was performed after two centrifugations (1'500 x g for $10 \mathrm{~min}$, then $10^{\prime} 000 \mathrm{x} \mathrm{g}$ for $20 \mathrm{~min}$ ) followed by one filtration $(0.8 \mu \mathrm{m})$ step.

Polymer precipitation was the strategy for Zhou et al. 2016,[87] although TEI kit was preferred. The cells that were used were purified human monocytes were obtained grown in 10\% exosome-free FBS.

\subsection{Characterization}

Saha et al. 2016 analyzed THP-1-derived EVs by NTA for size and concentration, and determined the protein content by Bradford assay. Li J et al. 2013[83] analyzed protein content by Bradford as well, but they additionally performed EM, immunoblot analysis of exosomal markers, and microarray analysis of exosomal mRNA and miRNA. 
Zhou et al. 2016 characterized their isolated EVs by EM, western blot for both EV and non-EV markers (Alix, LAMP2, cytochrome c, HSP70, CD63, GAPDH) and immunofluorescence; macrophage-EVs were labelled with the PKH67 dye, then given to Huh-7 cells and observed by fluorescence microscopy.

Future reports about EVs from Kupffer cells can expand the existing literature by providing additional insights into storage and yield optimization practices.

\subsection{Interspecies method transferability}

While Eguchi et al. 2017[36] had been very thorough in their analysis of hepatocyte-EVs (FACS, DLS, TEM, miRNA, see chapter 2), they also took a look at the EVs shed by hepatic macrophages they isolated from mice, and compared the two in terms of morphology (TEM) and concentration (FACS).

Nojima et al. 2016[65,66] reported working with EVs originating from mice Kupffer cells. The EVs were isolated by differential centrifugation ( $300 \mathrm{x} \mathrm{g}$ for $10 \mathrm{~min}$, then $16^{\prime} 000 \mathrm{xg}$ for $30 \mathrm{~min}$ ), after which the supernatant was filtred through a $0.22 \mu \mathrm{m}$ membrane. EVs were subsequently collected after two UC steps $(120,000 \times \mathrm{g}$ for $70 \mathrm{~min})$. The EV-pellet was re-suspended in PBS and purified on a Tris/sucrose/D2O density cushion UC (100'000 $\mathrm{x} \mathrm{g}$ for $90 \mathrm{~min})$. EVs were then transferred into a new tube, and collected after one final UC step (120'000 $\mathrm{g}$ for $70 \mathrm{~min}$ ). EV yields under different conditions were precisely reported, as well as the activity of neutral ceramidase and sphingosine kinase.

\section{EVs from liver stem cells}

Several studies have suggested the presence of liver-resident stem cells, which along with hepatocytes contribute to liver regeneration, but it remains a controversial topic, as reviewed elsewhere.[264] The identification of oval cells and their role in liver regeneration contributes to our current understanding of the process,[265] more confidently so after establishing their precursor role to hepatocytes,[266] and their localization in the canals of Hering[267] between bile capillaries and interlobular bile ducts (Figure 2). A population of more committed hepatic stem/progenitor cells known as small hepatocytes had been first observed in rat cells in 1992,[268] and subsequently isolated from both adult rats[269] and humans.[270]

Herrera et al. 2006[271], were able to isolate a human liver stem-like cell (HLSC) population expressing markers of mesenchymal (but not hematopoietic) stem cells from the tissues of adult human livers and from cryopreserved primary human hepatocytes. HLSCs showed the ability to self-renew and to differentiate into osteogenic, endothelial and insulin-producing cells, while starting with a partial commitment to the hepatocyte lineage. Since 2006 , it has been regularly reported on HSLC and HLSCderived EVs.[88-97]

\subsection{Isolation strategies}


For the isolation of EVs described in the following paragraph, HLSCs were cultured in the absence of FBS prior to cell culture medium collection, and their documented viability was between 97 and $99 \%$, obviating concerns about co-isolation of FBS-EVs and limiting the presence of apoptotic bodies.

The article by Herrera et al. from 2014[88-97] exemplifies the group's general preference of differential centrifugation (including UC)[88-97] for EV isolation: after performing two centrifugations at $3^{\prime} 000 \times \mathrm{g}$ for $20 \mathrm{~min}$ to remove cells and debris, EVs were isolated by $2 \mathrm{~h} \mathrm{UC}\left(100^{\prime} 000 \times \mathrm{g}, 4^{\circ} \mathrm{C}\right)$. EVs were then either used fresh or after storing them at $-80^{\circ} \mathrm{C}$ (resuspended in RPMI with $5 \%(\mathrm{v} / \mathrm{v}$ ) dimethyl sulfoxide). They provided precise storing conditions and reported no differences in the biochemical activity between freshly used and stored EVs.

Variations of this protocol can be found in other articles published by this group. For example, Herrera had opted for a single centrifugation at 2'000 $\mathrm{xg}$ for $20 \mathrm{~min}$ followed by two UC steps (100'000 $\mathrm{xg}$ ) of 1 $\mathrm{h}$ each in 2010,[90] and then modified the protocol again to one centrifugation at 3'000 x g for $20 \mathrm{~min}$, a second one at 10'000 x g for $1 \mathrm{~h}$, and a final UC (100'000 x g) for $1 \mathrm{~h}$.[92] Gualerzi et al. 2019[97] added a size exclusion chromatography (SEC) purification step.

Interestingly, Deregibus et al. in 2016[98] proposed an alternative approach by developing a custom charge-based strategy for EV isolation, in which they use protamine and PEG $35 \mathrm{kDa}$.[98] A comparison with commercially available precipitation kits was not performed, but their method yielded results that were comparable to the UC approach in terms of EV-quality, and higher in terms of isolated EV-quantity (not only in cell cultures but also in serum and saliva samples, see chapter 8).

\subsection{Characterization}

Herrera et. al 2014 offers many of the characterization steps of HLSC-EV. Size distribution was determined by NTA. To trace EVs by fluorescent microscopy, EVs were labeled with $1 \mu \mathrm{M}$ Dil dye. Cytofluorimetric analysis was done using fluorescein isothiocyanate, phycoerythrin or allophycocyanin conjugated antibodies (CD73, CD44, CD105, CD90, CD107, CD63, CD29, CD81, CD146, HLA-class I). They also performed FACS after absorption on beads by incubating $10 \mu \mathrm{g} \mathrm{EVs}$ with latex beads then with the aforementioned antibodies. EV protein content was quantified by Bradford assay; immunoblotting was also performed (CD63, CD81, Alix and Hsp9).

Additional characterization for HLSC-EVs include zeta potential, TEM and analysis of RNA (Deregibus et al. 2016), as well as a novel method based on Raman spectroscopy for purity determination established by Gualerzi et al. 2019.[97] The method used Raman spectra to measure the protein-tolipid and nucleic acid-to-lipid ratios.

\subsection{Interspecies method transferability}

Liver stem cell EVs originating from rats have been described by Ichinohe et al. in 2017.[99] The liver resident stem/progenitor cells used were isolated by their research group before[272] (Thy1-positive cells[273]), but it is difficult to directly compare them to the HLSCs because there are no studies comparing their EVs. EVs from Thy+ cells were isolated using the commercially available precipitation kit ExoQuick ${ }^{\mathrm{TM}}$, and the described characterization was limited to EV quantification by NanoDrop 1000 
spectrometer, since they administered $1.6 \mu \mathrm{g}$ of EVs to different liver cells and look at their effect on cell morphology, proliferation and IL17rb receptor expression.

\section{EVs from clinical settings}

There has been extensive research delving into the diagnostic potential of EVs in the context of liverassociated conditions, albeit mostly looking into circulating vesicles, both in human patients[100-159] and in rodents.[215-251] The increased complexity of the system makes it difficult to trace their origin back to a specific cell type, but first efforts have been made to make that connection. We will highlight here research that endeavored to connect previously discussed in vitro settings to ex vivo findings.

\subsection{Isolation strategies}

Liver-derived EVs have been recovered in and ex vivo from liver blood directly,[160] bile[161] and even from cancer cells that were extracted intraoperatively.[162] The isolation of EVs from human patients mirrored protocols developed for cell culture systems, with differential centrifugation (including UC) $[32,36-38,62,63,83,220]$ and polymer precipitation (ExoQuick ${ }^{\mathrm{TM}}$ and TEI) $[70,77,86,209,221]$ being the most prevalent approaches. Samples collected from blood circulation are consistently stored at -80 ${ }^{\circ} \mathrm{C}$, mostly after depleting them of cells and platelets.

\subsection{Characterization}

Typically, the analysis of circulating EVs is focused on the biomarkers of interest. For example, Sohn et al. 2015[136] analysed the expression levels of serum exosomal microRNAs (miR-18a, -21, -93, -106b, $-221,-222$ and $-224,-101,-122$ and -195$)$ of patients suffering from different liver conditions including chronic hepatitis $\mathrm{B}$, liver cirrhosis and hepatocellular carcinoma. This also tends to happen when looking at specific cells. For example, Brandon-Warner et al. 2016,[70] who collected EVs from HSCs in vitro as well as from human plasma, performed RNA isolation using exoEasy ${ }^{\mathrm{TM}}$ serum and plasma kit, followed by QiaZol total RNA purification; for exomes they only show miR data.

\subsection{Interspecies method transferability}

Nojima et al. 2016[66][65] isolated EVs from primary mice hepatocytes and Kupffer cells in vitro by differential UC and sucrose gradient, while in the same studies describe also mice serum-derived EVs (even from cardiac puncture[65]) being isolated by ExoQuick ${ }^{\mathrm{TM}}$. The isolation strategies were not transferred from in vitro to ex vivo in these cases, but the characterization practices (DLS for size, CD81antigen-ELISA for quantification) were.

Lambrecht et al. 2017[77] evaluated the levels of miRNA-122, -150, -192, -21, -200b, and -92a by qRTPCR from human plasma samples as well as from primary mice HSCs. In both instances, EV isolation 
was performed by TEI. Duan et al. 2019[62] compared compared findings from primary rat hepatocytes and human plasma. A wider comparison was performed by Hirsova et al. 2016:[63] Huh7 cells and primary mice hepatocytes both served as in vitro models in addition to their research with ex vivo human samples. In their research with cholangiocytes, Li X. et al. 2018[81] looked at EVs isolated from primary mice cells in vitro, but took it a step further ex vivo, evaluating both murine and human sera-derived EVs. Their methods included differential centrifugation (with a UC step) for EV-isolation, DLS and TEM for size analysis and assessment of mRNA H19 levels. Cho et al. 2017[32] isolated EVs from a variety of samples as well: human cell lines (HepG2, He3B), rat primary hepatocytes, human sera, rat sera. While differential centrifugation worked in vitro, they noted how extra steps were required ex vivo to reduce contamination with plasma proteins (e.g., albumin). EV isolation from plasma samples was thus optimized by comparing three alternative methods: density gradient UC (30\% Optiprep), ExoQuick ${ }^{\mathrm{TM}}$, and an optimized ExoQuick ${ }^{\mathrm{TM}}$ protocol, which included 3 washing steps. Deregibus et al. 2016[98] were perhaps more interesting from a methodological transferability perspective, since they compared the performance of a custom charge-based precipitation method to differential UC, using samples derived from HLSCs (see chapter 7), human serum and human saliva.

\section{Final general remarks}

Strategies for liver-derived EV isolation and characterization are as varied as the research groups tackling the challenge. While the main advantages and disadvantages for each approach have been presented, we would like to highlight some of the key aspects that emerged.

FBS handling. Cell culture approaches have become indispensable to simplify EV research before diving into significantly more complex ex vivo samples, but most cell lines require FBS for optimal growth. Depriving them of it might easily result in additional stress that will affect results to an unpredictable extent. Alternatives to FBS have already been proposed, such as chemically defined media or human platelet lysate[274] and these may replace FBS-supplemented cell culture models.[275] Cells can be successively deprived of FBS to limit the impact of outright elimination of it, but more frequently than that, research groups opt to depleting their FBS of EVs by ultracentrifugation prior to use or they directly use commercially available ExoFreeFBS. The experimental validation for either of these steps is rarely reported, but it would be an important addition given the questionable efficacy of some the most common methods.[229] Even under serum-replacement conditions, miRNA contaminants have reportedly been found.[276] Whenever serums starvation (i.e., culturing without serum) is feasible, it would be the preferred option.

Cell viability. Looking at the EVs collected in vitro, the cell number and viability at EV-harvest are seldom mentioned. Depending on the study, $90-99 \%$ vital cells is what was deemed appropriate when documented at all. As even a few dead cells can contribute to the presence of apoptotic bodies that can influence the EV-population it is important to report the number of viable cells in each study.[1]

Yield. EV yield directly impacts the characterization possibilities because it determines whether there is enough material to perform analyses such as cryo-TEM imaging. It also speaks to the efficiency of the 
isolation methods., revealing how well does a specific technique perform, especially when compared to alternatives. An absolute yield would also allow to evaluate upstream applicability, i.e., whether mass production would be a feasible option or not (e.g. for the use of liver-derived EVs as drug delivery systems). Because of all of these considerations, the importance of disclosing and being able to compare this data is easy to see, yet when looking at the quantification of EV-recovery, we found the information either omitted/lacking or hard to extrapolate and ultimately to compare between studies. The particle number per million cells measure would be a convenient option to express the yield and to compare its efficiency across studies. Quantification by mass of EV-associated proteins would also be viable alternative, if other co-isolated proteins can be excluded, preferably by number of cells as well.

Storage. EV storage is a particularly relevant subject when EV isolation and characterization are not performed on the same day, which is often the case given how much time most of the described protocols require. Storage insights were not always provided, and their validation even less frequently. It has already been reported that storage modality can affect the EVs[277-279] which is why we think it is important to share this information. Trehalose, mannitol and polyethylene glycol had been evaluated as possible cryoprotectants in the aforementioned studies, although not in the context of liver-derived EVs as of yet. With the exception of dimethyl sulfoxide,[88-97] the use of cryoprotectants for storage below $-20^{\circ} \mathrm{C}$ is rarely considered.

Differences in differential (ultra-)centrifugation. This isolation technique has become the gold standard in EV research for the very good reason that it works. It is cited in well over half the articles referenced in this review, but the protocols are not standardized. Even when analyzing EVs originating from the same cell types, different groups tend to have different approaches with sometimes unexplained differences arise within the same group which makes comparison challenging. The number of centrifugation steps vary and, the relative centrifugal forces and centrifugal times applied at each step are rarely consistent. When there is sufficient purity validation and subsequent sample characterization, this methodological diversity might not be an insurmountable issue, but it is worth keeping it in mind when comparing results, and also when choosing which protocol to follow.

Suboptimal method description. There is a general lack of rigorous standardization of methods in EV research, that was addressed with a position paper first published in 2014,[280] then expended upon in 2018.[1] EV-TRACK is a platform aiming at method transparency. Methods descriptions could be shared on EV-TRACK when the information would otherwise be left out of a publication. Implementing this would improve reproducibility and, more nuancedly, it would allow to compare method efficiencies across studies. Experimental validation of some practices is not always shared, which may be a problem when the methods used have been reported to have weaknesses, such as depletion of FBS-EVs. The growing community working on EVs is becoming more aware of the need for standardization in this young field of research,[281] and the MISEV guidelines[1] remain undoubtedly the reference text in these regards.

\section{Conclusions and perspectives}


We reviewed the current methodological practices for the isolation and analysis of those liver derived $\mathrm{EVs}$, making a cell type specific user guide. Liver-derived EVs are gaining attention as a research topic, and there are already a few research papers addressing EVs from every liver resident cell type. Much work has already been published, but a rigorous standardization is needed. We moreover highlighted common causes for concern and critically reviewed room for improvement: the bigger issue that emerged was suboptimal method description and transparency.

We found hepatocyte-derived EVs to be analyzed the most, perspective studies might tackle EVs originating from other cell types more frequently. EVs from human induced pluripotent stem cells (iPSC)derived hepatocyte like cells have not been analysed in detail yet, even though these cells are being taken under consideration as cell culture models for the liver.[282-284] EVs from iPSCs have been studied in the context of liver fibrosis, but they were still not differentiated into hepatocyte like cells.[285] The method transferability and translational applicability have also been a prominent topic of our discussion because working with EVs is inherently complicated even in single cell cultures, but many researchers have endeavored to escalate the challenge to co-cultures systems, to animal models (rodents), and to human patients. The comparisons have not always been complete, but the efforts put into positively tracing EVs and their associated biomolecules back to a specific cell type in increasingly more complex settings are a first important step to better understand liver diseases and we hope to see more of that in the future.

\section{Acknowledgements}

G.F. is a holder of a NanoMatFutur grant from the Federal Ministry of Research and Education (13XP5029A). The Phospholipids Research Center is gratefully acknowledged for its support.

\section{References}

[1] C. Théry, K.W. Witwer, E. Aikawa, M.J. Alcaraz, J.D. Anderson, R. Andriantsitohaina, A. Antoniou, T. Arab, F. Archer, G.K. Atkin-Smith, D.C. Ayre, J.-M. Bach, D. Bachurski, H. Baharvand, L. Balaj, S. Baldacchino, N.N. Bauer, A.A. Baxter, M. Bebawy, C. Beckham, A. Bedina Zavec, A. Benmoussa, A.C. Berardi, P. Bergese, E. Bielska, C. Blenkiron, S. BobisWozowicz, E. Boilard, W. Boireau, A. Bongiovanni, F.E. Borràs, S. Bosch, C.M. Boulanger, X. Breakefield, A.M. Breglio, M.Á. Brennan, D.R. Brigstock, A. Brisson, M.L. Broekman, J.F. Bromberg, P. Bryl-Górecka, S. Buch, A.H. Buck, D. Burger, S. Busatto, D. Buschmann, B. Bussolati, E.I. Buzás, J.B. Byrd, G. Camussi, D.R. Carter, S. Caruso, L.W. Chamley, Y.-T. Chang, C. Chen, S. Chen, L. Cheng, A.R. Chin, A. Clayton, S.P. Clerici, A. Cocks, E. Cocucci, R.J. Coffey, A. Cordeiro-da-Silva, Y. Couch, F.A. Coumans, B. Coyle, R. Crescitelli, M.F. Criado, C. D'Souza-Schorey, S. Das, A. Datta Chaudhuri, P. de Candia, E.F. De Santana, O. De Wever, H.A. Del Portillo, T. Demaret, S. Deville, A. Devitt, B. Dhondt, D. Di Vizio, L.C. Dieterich, V. Dolo, A.P. Dominguez Rubio, M. Dominici, M.R. Dourado, T.A. Driedonks, F. V Duarte, H.M. Duncan, R.M. Eichenberger, K. Ekström, S. El Andaloussi, C. Elie-Caille, U. 
Erdbrügger, J.M. Falcón-Pérez, F. Fatima, J.E. Fish, M. Flores-Bellver, A. Försönits, A. FreletBarrand, F. Fricke, G. Fuhrmann, S. Gabrielsson, A. Gámez-Valero, C. Gardiner, K. Gärtner, R. Gaudin, Y.S. Gho, B. Giebel, C. Gilbert, M. Gimona, I. Giusti, D.C. Goberdhan, A. Görgens, S.M. Gorski, D.W. Greening, J.C. Gross, A. Gualerzi, G.N. Gupta, D. Gustafson, A. Handberg, R.A. Haraszti, P. Harrison, H. Hegyesi, A. Hendrix, A.F. Hill, F.H. Hochberg, K.F. Hoffmann, B. Holder, H. Holthofer, B. Hosseinkhani, G. Hu, Y. Huang, V. Huber, S. Hunt, A.G.-E. Ibrahim, T. Ikezu, J.M. Inal, M. Isin, A. Ivanova, H.K. Jackson, S. Jacobsen, S.M. Jay, M. Jayachandran, G. Jenster, L. Jiang, S.M. Johnson, J.C. Jones, A. Jong, T. Jovanovic-Talisman, S. Jung, R. Kalluri, S.-I. Kano, S. Kaur, Y. Kawamura, E.T. Keller, D. Khamari, E. Khomyakova, A. Khvorova, P. Kierulf, K.P. Kim, T. Kislinger, M. Klingeborn, D.J. Klinke, M. Kornek, M.M. Kosanović, Á.F. Kovács, E.-M. Krämer-Albers, S. Krasemann, M. Krause, I. V Kurochkin, G.D. Kusuma, S. Kuypers, S. Laitinen, S.M. Langevin, L.R. Languino, J. Lannigan, C. Lässer, L.C. Laurent, G. Lavieu, E. Lázaro-Ibáñez, S. Le Lay, M.-S. Lee, Y.X.F. Lee, D.S. Lemos, M. Lenassi, A. Leszczynska, I.T. Li, K. Liao, S.F. Libregts, E. Ligeti, R. Lim, S.K. Lim, A. Linē, K. Linnemannstöns, A. Llorente, C.A. Lombard, M.J. Lorenowicz, Á.M. Lörincz, J. Lötvall, J. Lovett, M.C. Lowry, X. Loyer, Q. Lu, B. Lukomska, T.R. Lunavat, S.L. Maas, H. Malhi, A. Marcilla, J. Mariani, J. Mariscal, E.S. Martens-Uzunova, L. Martin-Jaular, M.C. Martinez, V.R. Martins, M. Mathieu, S. Mathivanan, M. Maugeri, L.K. McGinnis, M.J. McVey, D.G. Meckes, K.L. Meehan, I. Mertens, V.R. Minciacchi, A. Möller, M. Møller Jørgensen, A. MoralesKastresana, J. Morhayim, F. Mullier, M. Muraca, L. Musante, V. Mussack, D.C. Muth, K.H. Myburgh, T. Najrana, M. Nawaz, I. Nazarenko, P. Nejsum, C. Neri, T. Neri, R. Nieuwland, L. Nimrichter, J.P. Nolan, E.N. Nolte-'t Hoen, N. Noren Hooten, L. O'Driscoll, T. O'Grady, A. O'Loghlen, T. Ochiya, M. Olivier, A. Ortiz, L.A. Ortiz, X. Osteikoetxea, O. Østergaard, M. Ostrowski, J. Park, D.M. Pegtel, H. Peinado, F. Perut, M.W. Pfaffl, D.G. Phinney, B.C. Pieters, R.C. Pink, D.S. Pisetsky, E. Pogge von Strandmann, I. Polakovicova, I.K. Poon, B.H. Powell, I. Prada, L. Pulliam, P. Quesenberry, A. Radeghieri, R.L. Raffai, S. Raimondo, J. Rak, M.I. Ramirez, G. Raposo, M.S. Rayyan, N. Regev-Rudzki, F.L. Ricklefs, P.D. Robbins, D.D. Roberts, S.C. Rodrigues, E. Rohde, S. Rome, K.M. Rouschop, A. Rughetti, A.E. Russell, P. Saá, S. Sahoo, E. Salas-Huenuleo, C. Sánchez, J.A. Saugstad, M.J. Saul, R.M. Schiffelers, R. Schneider, T.H. Schøyen, A. Scott, E. Shahaj, S. Sharma, O. Shatnyeva, F. Shekari, G.V. Shelke, A.K. Shetty, K. Shiba, P.R.-M. Siljander, A.M. Silva, A. Skowronek, O.L. Snyder, R.P. Soares, B.W. Sódar, C. Soekmadji, J. Sotillo, P.D. Stahl, W. Stoorvogel, S.L. Stott, E.F. Strasser, S. Swift, H. Tahara, M. Tewari, K. Timms, S. Tiwari, R. Tixeira, M. Tkach, W.S. Toh, R. Tomasini, A.C. Torrecilhas, J.P. Tosar, V. Toxavidis, L. Urbanelli, P. Vader, B.W. van Balkom, S.G. van der Grein, J. Van Deun, M.J. van Herwijnen, K. Van Keuren-Jensen, G. van Niel, M.E. van Royen, A.J. van Wijnen, M.H. Vasconcelos, I.J. Vechetti, T.D. Veit, L.J. Vella, É. Velot, F.J. Verweij, B. Vestad, J.L. Viñas, T. Visnovitz, K. V Vukman, J. Wahlgren, D.C. Watson, M.H. Wauben, A. Weaver, J.P. Webber, V. Weber, A.M. Wehman, D.J. Weiss, J.A. Welsh, S. Wendt, A.M. Wheelock, Z. Wiener, L. Witte, J. Wolfram, A. Xagorari, P. Xander, J. Xu, X. Yan, M. Yáñez-Mó, H. Yin, Y. Yuana, V. Zappulli, J. Zarubova, V. Žėkas, J.-Y. Zhang, Z. Zhao, L. Zheng, A.R. Zheutlin, A.M. Zickler, P. Zimmermann, A.M. Zivkovic, D. Zocco, E.K. 
Zuba-Surma, A.M. Zickler, P. Zimmermann, A.M. Zivkovic, D. Zocco, E.K. Zuba-Surma, Minimal information for studies of extracellular vesicles 2018 (MISEV2018): a position statement of the International Society for Extracellular Vesicles and update of the MISEV2014 guidelines., J. Extracell. Vesicles. 7 (2018) 1535750.

https://doi.org/10.1080/20013078.2018.1535750.

[2] K.W. Witwer, C. Théry, Extracellular vesicles or exosomes? On primacy, precision, and popularity influencing a choice of nomenclature., J. Extracell. Vesicles. 8 (2019) 1648167. https://doi.org/10.1080/20013078.2019.1648167.

[3] G. van Niel, G. D’Angelo, G. Raposo, Shedding light on the cell biology of extracellular vesicles, Nat. Rev. Mol. Cell Biol. 19 (2018) 213-228. https://doi.org/10.1038/nrm.2017.125.

[4] P.D. Stahl, G. Raposo, Exosomes and extracellular vesicles: the path forward, Essays Biochem. 62 (2018) 119-124. https://doi.org/10.1042/EBC20170088.

[5] O.G. de Jong, S.A.A. Kooijmans, D.E. Murphy, L. Jiang, M.J.W. Evers, J.P.G. Sluijter, P. Vader, R.M. Schiffelers, Drug Delivery with Extracellular Vesicles: From Imagination to Innovation, Acc. Chem. Res. (2019) acs.accounts.9b00109. https://doi.org/10.1021/acs.accounts.9b00109.

[6] A. Goes, G. Fuhrmann, Biogenic and Biomimetic Carriers as Versatile Transporters To Treat Infections, ACS Infect. Dis. 4 (2018) 881-892. https://doi.org/10.1021/acsinfecdis.8b00030.

[7] Y. Kawamura, Y. Yamamoto, T.-A. Sato, T. Ochiya, Extracellular vesicles as trans-genomic agents: Emerging roles in disease and evolution., Cancer Sci. 108 (2017) 824-830. https://doi.org/10.1111/cas.13222.

[8] R. Ono, Y. Yasuhiko, K. Aisaki, S. Kitajima, J. Kanno, Y. Hirabayashi, Exosome-mediated horizontal gene transfer occurs in double-strand break repair during genome editing, Commun. Biol. 2 (2019) 57. https://doi.org/10.1038/s42003-019-0300-2.

[9] E. Woith, G. Fuhrmann, M.F. Melzig, Extracellular Vesicles-Connecting Kingdoms, Int. J. Mol. Sci. 20 (2019) 5695. https://doi.org/10.3390/ijms20225695.

[10] B. Wang, D. Xing, Y. Zhu, S. Dong, B. Zhao, The State of Exosomes Research: A Global Visualized Analysis, Biomed Res. Int. 2019 (2019) 1-10. https://doi.org/10.1155/2019/1495130.

[11] H. Kalra, R.J. Simpson, H. Ji, E. Aikawa, P. Altevogt, P. Askenase, V.C. Bond, F.E. Borràs, X. Breakefield, V. Budnik, E. Buzas, G. Camussi, A. Clayton, E. Cocucci, J.M. Falcon-Perez, S. Gabrielsson, Y.S. Gho, D. Gupta, H.C. Harsha, A. Hendrix, A.F. Hill, J.M. Inal, G. Jenster, E.M. Krämer-Albers, S.K. Lim, A. Llorente, J. Lötvall, A. Marcilla, L. Mincheva-Nilsson, I. Nazarenko, R. Nieuwland, E.N.M.N.'tt Hoen, A. Pandey, T. Patel, M.G. Piper, S. Pluchino, T.S.K. Prasad, L. Rajendran, G. Raposo, M. Record, G.E. Reid, F. Sánchez-Madrid, R.M. Schiffelers, P. Siljander, A. Stensballe, W. Stoorvogel, D. Taylor, C. Thery, H. Valadi, B.W.M. van Balkom, J. Vázquez, M. Vidal, M.H.M. Wauben, M. Yáñez-Mó, M. Zoeller, S. Mathivanan, Vesiclepedia: A Compendium for Extracellular Vesicles with Continuous Community Annotation, PLoS Biol. 10 (2012) e1001450. https://doi.org/10.1371/JOURNAL.PBIO.1001450.

[12] D.-K. Kim, B. Kang, O.Y. Kim, D. Choi, J. Lee, S.R. Kim, G. Go, Y.J. Yoon, J.H. Kim, S.C. Jang, K.-S. Park, E.-J. Choi, K.P. Kim, D.M. Desiderio, Y.-K. Kim, J. Lötvall, D. Hwang, Y.S. Gho, EVpedia: an integrated database of high-throughput data for systemic analyses of 
extracellular vesicles, J. Extracell. Vesicles. 2 (2013) 20384.

https://doi.org/10.3402/jev.v2i0.20384.

[13] J. Van Deun, P. Mestdagh, P. Agostinis, Ö. Akay, S. Anand, J. Anckaert, Z.A. Martinez, T. Baetens, E. Beghein, L. Bertier, G. Berx, J. Boere, S. Boukouris, M. Bremer, D. Buschmann, J.B. Byrd, C. Casert, L. Cheng, A. Cmoch, D. Daveloose, E. De Smedt, S. Demirsoy, V. Depoorter, B. Dhondt, T.A.P. Driedonks, A. Dudek, A. Elsharawy, I. Floris, A.D. Foers, K. Gärtner, A.D. Garg, E. Geeurickx, J. Gettemans, F. Ghazavi, B. Giebel, T.G. Kormelink, G. Hancock, H. Helsmoortel, A.F. Hill, V. Hyenne, H. Kalra, D. Kim, J. Kowal, S. Kraemer, P. Leidinger, C. Leonelli, Y. Liang, L. Lippens, S. Liu, A. Lo Cicero, S. Martin, S. Mathivanan, P. Mathiyalagan, T. Matusek, G. Milani, M. Monguió-Tortajada, L.M. Mus, D.C. Muth, A. Németh, E.N.M. Nolte-'t Hoen, L. O'Driscoll, R. Palmulli, M.W. Pfaffl, B. Primdal-Bengtson, E. Romano, Q. Rousseau, S. Sahoo, N. Sampaio, M. Samuel, B. Scicluna, B. Soen, A. Steels, J. V Swinnen, M. Takatalo, S. Thaminy, C. Théry, J. Tulkens, I. Van Audenhove, S. van der Grein, A. Van Goethem, M.J. van Herwijnen, G. Van Niel, N. Van Roy, A.R. Van Vliet, N. Vandamme, S. Vanhauwaert, G. Vergauwen, F. Verweij, A. Wallaert, M. Wauben, K.W. Witwer, M.I. Zonneveld, O. De Wever, J. Vandesompele, A. Hendrix, EV-TRACK: transparent reporting and centralizing knowledge in extracellular vesicle research, Nat. Methods. 14 (2017) 228-232. https://doi.org/10.1038/nmeth.4185.

[14] M.I. Ramirez, M.G. Amorim, C. Gadelha, I. Milic, J.A. Welsh, V.M. Freitas, M. Nawaz, N. Akbar, Y. Couch, L. Makin, F. Cooke, A.L. Vettore, P.X. Batista, R. Freezor, J.A. Pezuk, L. RosaFernandes, A.C.O. Carreira, A. Devitt, L. Jacobs, I.T. Silva, G. Coakley, D.N. Nunes, D. Carter, G. Palmisano, E. Dias-Neto, Technical challenges of working with extracellular vesicles, Nanoscale. 10 (2018) 881-906. https://doi.org/10.1039/C7NR08360B.

[15] J. Jablonska, M. Pietrowska, S. Ludwig, S. Lang, B.K. Thakur, J. Jablonska, M. Pietrowska, S. Ludwig, S. Lang, B.K. Thakur, Challenges in the Isolation and Proteomic Analysis of Cancer Exosomes_Implications for Translational Research, Proteomes. 7 (2019) 22. https://doi.org/10.3390/proteomes7020022.

[16] E. Trefts, M. Gannon, D.H. Wasserman, The liver., Curr. Biol. 27 (2017) R1147-R1151. https://doi.org/10.1016/j.cub.2017.09.019.

[17] S.K. Asrani, H. Devarbhavi, J. Eaton, P.S. Kamath, Burden of liver diseases in the world, J. Hepatol. 70 (2019) 151-171. https://doi.org/10.1016/j.jhep.2018.09.014.

[18] L. Pimpin, H. Cortez-Pinto, F. Negro, E. Corbould, J. V. Lazarus, L. Webber, N. Sheron, Burden of liver disease in Europe: Epidemiology and analysis of risk factors to identify prevention policies, J. Hepatol. 69 (2018) 718-735. https://doi.org/10.1016/j.jhep.2018.05.011.

[19] N. Ndugga, T.G. Lightbourne, K. Javaherian, J. Cabezas, N. Verma, A.S. Barritt, R. Bataller, R. Bataller, Disparities between research attention and burden in liver diseases: implications on uneven advances in pharmacological therapies in Europe and the USA., BMJ Open. 7 (2017) e013620. https://doi.org/10.1136/bmjopen-2016-013620.

[20] D. Povero, A. Eguchi, H. Li, C.D. Johnson, B.G. Papouchado, A. Wree, K. Messer, A.E. Feldstein, Circulating extracellular vesicles with specific proteome and liver microRNAs are potential biomarkers for liver injury in experimental fatty liver disease., PLoS One. 9 (2014) 
e113651. https://doi.org/10.1371/journal.pone.0113651.

[21] S. Urban, T. Mocan, H. Sänger, V. Lukacs-Kornek, M. Kornek, Extracellular Vesicles in Liver Diseases: Diagnostic, Prognostic, and Therapeutic Application, Semin. Liver Dis. 39 (2019) 070-077. https://doi.org/10.1055/s-0038-1676122.

[22] S. Sung, J. Kim, Y. Jung, Liver-Derived Exosomes and Their Implications in Liver Pathobiology., Int. J. Mol. Sci. 19 (2018). https://doi.org/10.3390/ijms19123715.

[23] K. Sato, L. Kennedy, S. Liangpunsakul, P. Kusumanchi, Z. Yang, F. Meng, S. Glaser, H. Francis, G. Alpini, K. Sato, L. Kennedy, S. Liangpunsakul, P. Kusumanchi, Z. Yang, F. Meng, S. Glaser, H. Francis, G. Alpini, Intercellular Communication between Hepatic Cells in Liver Diseases, Int. J. Mol. Sci. 20 (2019) 2180. https://doi.org/10.3390/ijms20092180.

[24] M.A. Angulo, F. Royo, J.M. Falcón-Pérez, Metabolic Nano-Machines: Extracellular Vesicles Containing Active Enzymes and Their Contribution to Liver Diseases, Curr. Pathobiol. Rep. (2019) 1-9. https://doi.org/10.1007/s40139-019-00197-3.

[25] F. Deng, N. Magee, Y. Zhang, Decoding the Role of Extracellular Vesicles in Liver Diseases., Liver Res. 1 (2017) 147-155. https://doi.org/10.1016/j.livres.2017.11.003.

[26] A.L. Mescher, L.C. Junqueira, Junqueira's basic histology : text and atlas, 12th ed., McGrawHill Medical, 2010.

[27] M. Berardocco, A. Radeghieri, S. Busatto, M. Gallorini, C. Raggi, C. Gissi, I. D’Agnano, P. Bergese, A. Felsani, A.C. Berardi, RNA-seq reveals distinctive RNA profiles of small extracellular vesicles from different human liver cancer cell lines., Oncotarget. 8 (2017) 8292082939. https://doi.org/10.18632/oncotarget.20503.

[28] T. Kogure, W.-L. Lin, I.K. Yan, C. Braconi, T. Patel, Intercellular nanovesicle-mediated microRNA transfer: A mechanism of environmental modulation of hepatocellular cancer cell growth, Hepatology. 54 (2011) 1237-1248. https://doi.org/10.1002/hep.24504.

[29] T. Kogure, I.K. Yan, W.-L. Lin, T. Patel, Extracellular Vesicle-Mediated Transfer of a Novel Long Noncoding RNA TUC339: A Mechanism of Intercellular Signaling in Human Hepatocellular Cancer., Genes Cancer. 4 (2013) 261-72. https://doi.org/10.1177/1947601913499020.

[30] W.-H. Xiao, G.-W. Sanren, J.-H. Zhu, Q.-W. Li, H.-R. Kang, R.-L. Wang, L.-P. Song, M. Ye, Effect of 5-aza-2'-deoxycytidine on immune-associated proteins in exosomes from hepatoma., World J. Gastroenterol. 16 (2010) 2371-7. https://doi.org/10.3748/wjg.v16.i19.2371.

[31] W. Xiao, W. Dong, C. Zhang, G. Saren, P. Geng, H. Zhao, Q. Li, J. Zhu, G. Li, S. Zhang, M. $Y e$, Effects of the epigenetic drug MS-275 on the release and function of exosome-related immune molecules in hepatocellular carcinoma cells., Eur. J. Med. Res. 18 (2013) 61. https://doi.org/10.1186/2047-783X-18-61.

[32] Y.-E. Cho, E.-J. Im, P.-G. Moon, E. Mezey, B.-J. Song, M.-C. Baek, Increased liver-specific proteins in circulating extracellular vesicles as potential biomarkers for drug- and alcoholinduced liver injury., PLoS One. 12 (2017) e0172463. https://doi.org/10.1371/journal.pone.0172463.

[33] Q. Rao, B. Zuo, Z. Lu, X. Gao, A. You, C. Wu, Z. Du, H. Yin, Tumor-derived exosomes elicit tumor suppression in murine hepatocellular carcinoma models and humans in vitro, 
Hepatology. 64 (2016) 456-472. https://doi.org/10.1002/hep.28549.

[34] J. Wei, L. Lv, Y. Wan, Y. Cao, G. Li, H. Lin, R. Zhou, C. Shang, J. Cao, H. He, Q. Han, P. Liu, G. Zhou, J. Min, Vps4A functions as a tumor suppressor by regulating the secretion and uptake of exosomal microRNAs in human hepatoma cells, Hepatology. 61 (2015) 1284-1294. https://doi.org/10.1002/hep.27660.

[35] J. Zhang, S. Lu, Y. Zhou, K. Meng, Z. Chen, Y. Cui, Y. Shi, T. Wang, Q.-Y. He, Motile hepatocellular carcinoma cells preferentially secret sugar metabolism regulatory proteins via exosomes, Proteomics. 17 (2017) 1700103. https://doi.org/10.1002/pmic.201700103.

[36] A. Eguchi, R.G. Lazaro, J. Wang, J. Kim, D. Povero, B. Williams, S.B. Ho, P. Stärkel, B. Schnabl, L. Ohno-Machado, H. Tsukamoto, A.E. Feldstein, Extracellular vesicles released by hepatocytes from gastric infusion model of alcoholic liver disease contain a MicroRNA barcode that can be detected in blood., Hepatology. 65 (2017) 475-490. https://doi.org/10.1002/hep.28838.

[37] J. Fang, Z. Zhang, L. Shang, Y. Luo, Y. Lin, Y. Yuan, S. Zhuang, Hepatoma cell-secreted exosomal microRNA-103 increases vascular permeability and promotes metastasis by targeting junction proteins, Hepatology. 68 (2018) 1459-1475. https://doi.org/10.1002/hep.29920.

[38] T. Fang, H. Lv, G. Lv, T. Li, C. Wang, Q. Han, L. Yu, B. Su, L. Guo, S. Huang, D. Cao, L. Tang, S. Tang, M. Wu, W. Yang, H. Wang, Tumor-derived exosomal miR-1247-3p induces cancerassociated fibroblast activation to foster lung metastasis of liver cancer., Nat. Commun. 9 (2018) 191. https://doi.org/10.1038/s41467-017-02583-0.

[39] A. Huang, J. Dong, S. Li, C. Wang, H. Ding, H. Li, X. Su, X. Ge, L. Sun, C. Bai, X. Shen, T. Fang, J. Li, N. Shao, Exosomal transfer of vasorin expressed in hepatocellular carcinoma cells promotes migration of human umbilical vein endothelial cells., Int. J. Biol. Sci. 11 (2015) 961-9. https://doi.org/10.7150/ijbs.11943.

[40] L.-H. Lv, Y.-L. Wan, Y. Lin, W. Zhang, M. Yang, G.-L. Li, H.-M. Lin, C.-Z. Shang, Y.-J. Chen, J. Min, Anticancer drugs cause release of exosomes with heat shock proteins from human hepatocellular carcinoma cells that elicit effective natural killer cell antitumor responses in vitro., J. Biol. Chem. 287 (2012) 15874-85. https://doi.org/10.1074/jbc.M112.340588.

[41] D. Povero, A. Eguchi, I.R. Niesman, N. Andronikou, X. de Mollerat du Jeu, A. Mulya, M. Berk, M. Lazic, S. Thapaliya, M. Parola, H.H. Patel, A.E. Feldstein, Lipid-induced toxicity stimulates hepatocytes to release angiogenic microparticles that require Vanin-1 for uptake by endothelial cells., Sci. Signal. 6 (2013) ra88. https://doi.org/10.1126/scisignal.2004512.

[42] D. Povero, N. Panera, A. Eguchi, C.D. Johnson, B.G. Papouchado, L. de Araujo Horcel, E.M. Pinatel, A. Alisi, V. Nobili, A.E. Feldstein, Lipid-Induced Hepatocyte-Derived Extracellular Vesicles Regulate Hepatic Stellate Cells via MicroRNA Targeting Peroxisome ProliferatorActivated Receptor- $ү$, Cmgh. 1 (2015) 646-663.e4.

https://doi.org/10.1016/j.jcmgh.2015.07.007.

[43] G.R. Raji, T.V. Sruthi, L. Edatt, K. Haritha, S. Sharath Shankar, V.B. Sameer Kumar, Horizontal transfer of miR-106a/b from cisplatin resistant hepatocarcinoma cells can alter the sensitivity of 
cervical cancer cells to cisplatin, Cell. Signal. 38 (2017) 146-158.

https://doi.org/10.1016/J.CELLSIG.2017.07.005.

[44] T. Tomiyama, G.-X. Yang, M. Zhao, W. Zhang, H. Tanaka, J. Wang, P.S. Leung, K. Okazaki, X.-S. He, Q. Lu, R.L. Coppel, C.L. Bowlus, M.E. Gershwin, The modulation of co-stimulatory molecules by circulating exosomes in primary biliary cirrhosis, Cell. Mol. Immunol. 14 (2017) 276. https://doi.org/10.1038/CMI.2015.86.

[45] S.E. Thacker, M. Nautiyal, M.A. Otieno, P.B. Watkins, M. Mosedale, Optimized Methods to Explore the Mechanistic and Biomarker Potential of Hepatocyte-Derived Exosomes in DrugInduced Liver Injury, Toxicol. Sci. 163 (2018) 92-100. https://doi.org/10.1093/toxsci/kfy015.

[46] V.K. Verma, H. Li, R. Wang, P. Hirsova, M. Mushref, Y. Liu, S. Cao, P.C. Contreras, H. Malhi, P.S. Kamath, G.J. Gores, V.H. Shah, Alcohol stimulates macrophage activation through caspase-dependent hepatocyte derived release of CD40L containing extracellular vesicles, J. Hepatol. 64 (2016) 651-660. https://doi.org/10.1016/J.JHEP.2015.11.020.

[47] Y. Xu, Y. Zhang, L. Wang, R. Zhao, Y. Qiao, D. Han, Q. Sun, N. Dong, Y. Liu, D. Wu, X. Zhang, N. Huang, N. Ma, W. Zhao, Y. Liu, X. Gao, miR-200a targets Gelsolin: A novel mechanism regulating secretion of microvesicles in hepatocellular carcinoma cells., Oncol. Rep. 37 (2017) 2711-2719. https://doi.org/10.3892/or.2017.5506.

[48] S. Cannito, E. Morello, C. Bocca, B. Foglia, E. Benetti, E. Novo, F. Chiazza, M. Rogazzo, R. Fantozzi, D. Povero, S. Sutti, E. Bugianesi, A.E. Feldstein, E. Albano, M. Collino, M. Parola, Microvesicles released from fat-laden cells promote activation of hepatocellular NLRP3 inflammasome: A pro-inflammatory link between lipotoxicity and non-alcoholic steatohepatitis., PLoS One. 12 (2017) e0172575. https://doi.org/10.1371/journal.pone.0172575.

[49] Y. Cao, L. Li, B. Han, Y. Wang, Y. Dai, J. Zhao, A catalytic molecule machine-driven biosensing method for amplified electrochemical detection of exosomes, Biosens. Bioelectron. 141 (2019) 111397. https://doi.org/10.1016/J.BIOS.2019.111397.

[50] L. Cheng, J. Liu, Q. Liu, Y. Liu, L. Fan, F. Wang, H. Yu, Y. Li, L. Bu, X. Li, W. Wei, H. Wang, G. Sun, Exosomes from Melatonin Treated Hepatocellularcarcinoma Cells Alter the Immunosupression Status through STAT3 Pathway in Macrophages., Int. J. Biol. Sci. 13 (2017) 723-734. https://doi.org/10.7150/ijbs.19642.

[51] K. Takahashi, I.K. Yan, T. Kogure, H. Haga, T. Patel, Extracellular vesicle-mediated transfer of long non-coding RNA ROR modulates chemosensitivity in human hepatocellular cancer., FEBS Open Bio. 4 (2014) 458-67. https://doi.org/10.1016/j.fob.2014.04.007.

[52] Y. Zhou, H. Ren, B. Dai, J. Li, L. Shang, J. Huang, X. Shi, Hepatocellular carcinoma-derived exosomal miRNA-21 contributes to tumor progression by converting hepatocyte stellate cells to cancer-associated fibroblasts., J. Exp. Clin. Cancer Res. 37 (2018) 324.

https://doi.org/10.1186/s13046-018-0965-2.

[53] H. Liu, W. Chen, X. Zhi, E.-J. Chen, T. Wei, J. Zhang, J. Shen, L.-Q. Hu, B. Zhao, X.-H. Feng, X.-L. Bai, T.-B. Liang, Tumor-derived exosomes promote tumor self-seeding in hepatocellular carcinoma by transferring miRNA-25-5p to enhance cell motility, Oncogene. 37 (2018) 49644978. https://doi.org/10.1038/s41388-018-0309-x.

[54] D.A. Cobb, O.-K. Kim, L. Golden-Mason, H.R. Rosen, Y.S. Hahn, Hepatocyte-derived 
exosomes promote $T$ follicular regulatory cell expansion during hepatitis $C$ virus infection., Hepatology. 67 (2018) 71-85. https://doi.org/10.1002/hep.29409.

[55] P.B. Devhare, R.B. Ray, Extracellular vesicles: Novel mediator for cell to cell communications in liver pathogenesis, Mol. Aspects Med. 60 (2018) 115-122. https://doi.org/10.1016/J.MAM.2017.11.001.

[56] M. He, H. Qin, T.C.W. Poon, S.-C. Sze, X. Ding, N.N. Co, S.-M. Ngai, T.-F. Chan, N. Wong, Hepatocellular carcinoma-derived exosomes promote motility of immortalized hepatocyte through transfer of oncogenic proteins and RNAs, Carcinogenesis. 36 (2015) 1008-1018. https://doi.org/10.1093/carcin/bgv081.

[57] A. Conigliaro, V. Costa, A. Lo Dico, L. Saieva, S. Buccheri, F. Dieli, M. Manno, S. Raccosta, C. Mancone, M. Tripodi, G. De Leo, R. Alessandro, CD90+ liver cancer cells modulate endothelial cell phenotype through the release of exosomes containing H19 IncRNA, Mol. Cancer. 14 (2015) 155. https://doi.org/10.1186/s12943-015-0426-x.

[58] N.R. Kapoor, R. Chadha, S. Kumar, T. Choedon, V.S. Reddy, V. Kumar, The HBx gene of hepatitis $B$ virus can influence hepatic microenvironment via exosomes by transferring its mRNA and protein, Virus Res. 240 (2017) 166-174.

https://doi.org/10.1016/J.VIRUSRES.2017.08.009.

[59] J.H. Fang, Z.J. Zhang, L.R. Shang, Y.W. Luo, Y.F. Lin, Y. Yuan, S.M. Zhuang, Hepatoma cellsecreted exosomal microRNA-103 increases vascular permeability and promotes metastasis by targeting junction proteins, Hepatology. 68 (2018) 1459-1475.

https://doi.org/10.1002/hep.29920.

[60] J.-Y. Wu, A.-L. Ji, Z.-X. Wang, G.-H. Qiang, Z. Qu, J.-H. Wu, C.-P. Jiang, Exosome-Mimetic Nanovesicles from Hepatocytes promote hepatocyte proliferation in vitro and liver regeneration in vivo., Sci. Rep. 8 (2018) 2471. https://doi.org/10.1038/s41598-018-20505-y.

[61] E. Rodríguez-Suárez, E. Gonzalez, C. Hughes, J. Conde-Vancells, A. Rudella, F. Royo, L. Palomo, F. Elortza, S.C. Lu, J.M. Mato, J.P.C. Vissers, J.M. Falcón-Pérez, Quantitative proteomic analysis of hepatocyte-secreted extracellular vesicles reveals candidate markers for liver toxicity., J. Proteomics. 103 (2014) 227-40. https://doi.org/10.1016/j.jprot.2014.04.008.

[62] L. Duan, A. Ramachandran, J.Y. Akakpo, J.L. Weemhoff, S.C. Curry, H. Jaeschke, Role of extracellular vesicles in release of protein adducts after acetaminophen-induced liver injury in mice and humans, Toxicol. Lett. 301 (2019) 125-132.

https://doi.org/10.1016/J.TOXLET.2018.11.005.

[63] P. Hirsova, S.H. Ibrahim, G.J. Gores, H. Malhi, Lipotoxic lethal and sublethal stress signaling in hepatocytes: relevance to NASH pathogenesis., J. Lipid Res. 57 (2016) 1758-1770. https://doi.org/10.1194/jlr.R066357.

[64] S.H. Ibrahim, A. Krishnan, S.F. Bronk, M.R. Charlton, G.J. Gores, V.H. Shah, H. Malhi, N.W. Werneburg, V.K. Verma, P. Hirsova, Lipid-Induced Signaling Causes Release of Inflammatory Extracellular Vesicles From Hepatocytes, Gastroenterology. 150 (2016) 956-967. https://doi.org/10.1053/j.gastro.2015.12.037.

[65] H. Nojima, T. Konishi, C.M. Freeman, R.M. Schuster, L. Japtok, B. Kleuser, M.J. Edwards, E. Gulbins, A.B. Lentsch, Chemokine Receptors, CXCR1 and CXCR2, Differentially Regulate 
Exosome Release in Hepatocytes, PLoS One. 11 (2016) e0161443.

https://doi.org/10.1371/journal.pone.0161443.

[66] H. Nojima, C.M. Freeman, R.M. Schuster, L. Japtok, B. Kleuser, M.J. Edwards, E. Gulbins, A.B. Lentsch, Hepatocyte exosomes mediate liver repair and regeneration via sphingosine-1phosphate, J. Hepatol. 64 (2016) 60-68. https://doi.org/10.1016/j.jhep.2015.07.030.

[67] L.-M. Li, H. Liu, X.-H. Liu, H.-B. Hu, S.-M. Liu, Clinical significance of exosomal miRNAs and proteins in three human cancers with high mortality in China., Oncol. Lett. 17 (2019) 11-22. https://doi.org/10.3892/ol.2018.9631.

[68] B. Ma, H. Jiang, J. Jia, L. Di, G. Song, J. Yu, Y. Zhu, Z. Lu, X. Wang, X. Zhou, J. Ren, Murine bone marrow stromal cells pulsed with homologous tumor-derived exosomes inhibit proliferation of liver cancer cells, Clin. Transl. Oncol. 14 (2012) 764-773. https://doi.org/10.1007/s12094-012-0860-9.

[69] E. Kakazu, A.S. Mauer, M. Yin, H. Malhi, Hepatocytes release ceramide-enriched proinflammatory extracellular vesicles in an IRE1a-dependent manner, J. Lipid Res. 57 (2016) 233. https://doi.org/10.1194/JLR.M063412.

[70] E. Brandon-Warner, N.A. Feilen, C.R. Culberson, C.O. Field, A.S. deLemos, M.W. Russo, L.W. Schrum, Processing of miR17-92 Cluster in Hepatic Stellate Cells Promotes Hepatic Fibrogenesis During Alcohol-Induced Injury, Alcohol. Clin. Exp. Res. 40 (2016) 1430-1442. https://doi.org/10.1111/acer.13116.

[71] A. Charrier, R. Chen, L. Chen, S. Kemper, T. Hattori, M. Takigawa, D.R. Brigstock, Exosomes mediate intercellular transfer of pro-fibrogenic connective tissue growth factor (CCN2) between hepatic stellate cells, the principal fibrotic cells in the liver, Surg. (United States). 156 (2014) 548-555. https://doi.org/10.1016/j.surg.2014.04.014.

[72] L. Chen, A. Charrier, Y. Zhou, R. Chen, B. Yu, K. Agarwal, H. Tsukamoto, L.J. Lee, M.E. Paulaitis, D.R. Brigstock, Epigenetic regulation of connective tissue growth factor by MicroRNA-214 delivery in exosomes from mouse or human hepatic stellate cells., Hepatology. 59 (2014) 1118-29. https://doi.org/10.1002/hep.26768.

[73] X. Wang, K.J. Kwak, Z. Yang, A. Zhang, X. Zhang, R. Sullivan, D. Lin, R.L. Lee, C. Castro, K. Ghoshal, C. Schmidt, L.J. Lee, Extracellular mRNA detected by molecular beacons in tethered lipoplex nanoparticles for diagnosis of human hepatocellular carcinoma., PLoS One. 13 (2018) e0198552. https://doi.org/10.1371/journal.pone.0198552.

[74] R.P. Witek, L. Yang, R. Liu, Y. Jung, A. Omenetti, W. Syn, S.S. Choi, Y. Cheong, C.M. Fearing, K.M. Agboola, W. Chen, A.M. Diehl, Liver Cell-Derived Microparticles Activate Hedgehog Signaling and Alter Gene Expression in Hepatic Endothelial Cells, Gastroenterology. 136 (2009) 320-330.e2. https://doi.org/10.1053/J.GASTRO.2008.09.066.

[75] L. Chen, R. Chen, V.M. Velazquez, D.R. Brigstock, Fibrogenic Signaling Is Suppressed in Hepatic Stellate Cells through Targeting of Connective Tissue Growth Factor (CCN2) by Cellular or Exosomal MicroRNA-199a-5p., Am. J. Pathol. 186 (2016) 2921-2933. https://doi.org/10.1016/j.ajpath.2016.07.011.

[76] L. Chen, D.R. Brigstock, Integrins and heparan sulfate proteoglycans on hepatic stellate cells (HSC) are novel receptors for HSC-derived exosomes., FEBS Lett. 590 (2016) 4263-4274. 
https://doi.org/10.1002/1873-3468.12448.

[77] J. Lambrecht, P.J. Poortmans, S. Verhulst, H. Reynaert, I. Mannaerts, L.A. van Grunsven, Circulating ECV-Associated miRNAs as Potential Clinical Biomarkers in Early Stage HBV and HCV Induced Liver Fibrosis, Front. Pharmacol. 8 (2017) 56.

https://doi.org/10.3389/FPHAR.2017.00056.

[78] L. Chen, R. Chen, S. Kemper, A. Charrier, D.R. Brigstock, Suppression of fibrogenic signaling in hepatic stellate cells by Twist1-dependent microRNA-214 expression: Role of exosomes in horizontal transfer of Twist1., Am. J. Physiol. Gastrointest. Liver Physiol. 309 (2015) G491-9. https://doi.org/10.1152/ajpgi.00140.2015.

[79] A. Arbelaiz, M. Azkargorta, M. Krawczyk, A. Santos-Laso, A. Lapitz, M.J. Perugorria, O. Erice, E. Gonzalez, R. Jimenez-Agüero, A. Lacasta, C. Ibarra, A. Sanchez-Campos, J.P. Jimeno, F. Lammert, P. Milkiewicz, M. Marzioni, R.I.R. Macias, J.J.G. Marin, T. Patel, G.J. Gores, I. Martinez, F. Elortza, J.M. Falcon-Perez, L. Bujanda, J.M. Banales, Serum extracellular vesicles contain protein biomarkers for primary sclerosing cholangitis and cholangiocarcinoma, Hepatology. 66 (2017) 1125-1143. https://doi.org/10.1002/hep.29291.

[80] K. Sato, F. Meng, J. Venter, T. Giang, S. Glaser, G. Alpini, The role of the secretin/secretin receptor axis in inflammatory cholangiocyte communication via extracellular vesicles., Sci. Rep. 7 (2017) 11183. https://doi.org/10.1038/s41598-017-10694-3.

[81] X. Li, R. Liu, Z. Huang, E.C. Gurley, X. Wang, J. Wang, H. He, H. Yang, G. Lai, L. Zhang, J.S. Bajaj, M. White, W.M. Pandak, P.B. Hylemon, H. Zhou, Cholangiocyte-derived exosomal long noncoding RNA H19 promotes cholestatic liver injury in mouse and humans, Hepatology. 68 (2018) 599-615. https://doi.org/10.1002/hep.29838.

[82] S. Giugliano, M. Kriss, L. Golden-Mason, E. Dobrinskikh, A.E.L. Stone, A. Soto-Gutierrez, A. Mitchell, S.R. Khetani, D. Yamane, M. Stoddard, H. Li, G.M. Shaw, M.G. Edwards, S.M. Lemon, M. Gale, V.H. Shah, H.R. Rosen, H.R. Rosen, Hepatitis C virus infection induces autocrine interferon signaling by human liver endothelial cells and release of exosomes, which inhibits viral replication., Gastroenterology. 148 (2015) 392-402.e13. https://doi.org/10.1053/j.gastro.2014.10.040.

[83] J. Li, K. Liu, Y. Liu, Y. Xu, F. Zhang, H. Yang, J. Liu, T. Pan, J. Chen, M. Wu, X. Zhou, Z. Yuan, Exosomes mediate the cell-to-cell transmission of IFN- $\alpha$-induced antiviral activity, Nat. Immunol. 14 (2013) 793-803. https://doi.org/10.1038/ni.2647.

[84] R. Wang, Q. Ding, U. Yaqoob, T.M. de Assuncao, V.K. Verma, P. Hirsova, S. Cao, D. Mukhopadhyay, R.C. Huebert, V.H. Shah, Exosome Adherence and Internalization by Hepatic Stellate Cells Triggers Sphingosine 1-Phosphate-dependent Migration., J. Biol. Chem. 290 (2015) 30684-96. https://doi.org/10.1074/jbc.M115.671735.

[85] A. Aucher, D. Rudnicka, D.M. Davis, MicroRNAs Transfer from Human Macrophages to Hepato-Carcinoma Cells and Inhibit Proliferation, J. Immunol. 191 (2013) 6250-60. https://doi.org/10.4049/JIMMUNOL.1301728.

[86] B. Saha, F. Momen-Heravi, K. Kodys, G. Szabo, MicroRNA Cargo of Extracellular Vesicles from Alcohol-exposed Monocytes Signals Naive Monocytes to Differentiate into M2 Macrophages., J. Biol. Chem. 291 (2016) 149-59. https://doi.org/10.1074/jbc.M115.694133. 
[87] Y. Zhou, X. Wang, L. Sun, L. Zhou, T.-C. Ma, L. Song, J.-G. Wu, J.-L. Li, W.-Z. Ho, Toll-like receptor 3-activated macrophages confer anti-HCV activity to hepatocytes through exosomes., FASEB J. 30 (2016) 4132-4140. https://doi.org/10.1096/fj.201600696R.

[88] V. Fonsato, F. Collino, M.B. Herrera, C. Cavallari, M.C. Deregibus, B. Cisterna, S. Bruno, R. Romagnoli, M. Salizzoni, C. Tetta, G. Camussi, Human Liver Stem Cell-Derived Microvesicles Inhibit Hepatoma Growth in SCID Mice by Delivering Antitumor MicroRNAs, Stem Cells. 30 (2012) 1985. https://doi.org/10.1002/STEM.1161.

[89] V. Fonsato, M. De Lena, S. Tritta, A. Brossa, R. Calvetti, C. Tetta, G. Camussi, B. Bussolati, Human liver stem cell-derived extracellular vesicles enhance cancer stem cell sensitivity to tyrosine kinase inhibitors through Akt/mTOR/PTEN combined modulation., Oncotarget. 9 (2018) 36151-36165. https://doi.org/10.18632/oncotarget.26319.

[90] M.B. Herrera, V. Fonsato, S. Gatti, M.C. Deregibus, A. Sordi, D. Cantarella, R. Calogero, B. Bussolati, C. Tetta, G. Camussi, Human liver stem cell-derived microvesicles accelerate hepatic regeneration in hepatectomized rats., J. Cell. Mol. Med. 14 (2010) 1605-18. https://doi.org/10.1111/j.1582-4934.2009.00860.x.

[91] M.B. Herrera Sanchez, S. Bruno, C. Grange, M. Tapparo, V. Cantaluppi, C. Tetta, G. Camussi, Human liver stem cells and derived extracellular vesicles improve recovery in a murine model of acute kidney injury., Stem Cell Res. Ther. 5 (2014) 124. https://doi.org/10.1186/scrt514.

[92] M.B. Herrera Sanchez, S. Previdi, S. Bruno, V. Fonsato, M.C. Deregibus, S. Kholia, S. Petrillo, E. Tolosano, R. Critelli, M. Spada, R. Romagnoli, M. Salizzoni, C. Tetta, G. Camussi, Extracellular vesicles from human liver stem cells restore argininosuccinate synthase deficiency, Stem Cell Res. Ther. 8 (2017) 176. https://doi.org/10.1186/s13287-017-0628-9.

[93] S. Kholia, M.B.H. Sanchez, M. Cedrino, E. Papadimitriou, M. Tapparo, M.C. Deregibus, M.F. Brizzi, C. Tetta, G. Camussi, Human Liver Stem Cell-Derived Extracellular Vesicles Prevent Aristolochic Acid-Induced Kidney Fibrosis, Front. Immunol. 9 (2018). https://doi.org/10.3389/FIMMU.2018.01639.

[94] T. Lopatina, C. Grange, V. Fonsato, M. Tapparo, A. Brossa, S. Fallo, A. Pitino, M.B. HerreraSanchez, S. Kholia, G. Camussi, B. Bussolati, Extracellular vesicles from human liver stem cells inhibit tumor angiogenesis, Int. J. Cancer. 144 (2019) 322-333.

https://doi.org/10.1002/ijc.31796.

[95] F.R.D.S.N.-T.D.R.C.G.M.G.R.M.P.S.C. Romagnoli;, N. De Stefano, V. Navarro-Tableros, E. David, G. Rizza, G. Catalano, N. Gilbo, F. Maione, F. Gonella, D. Roggio, S. Martini, D. Patrono, M. Salizzoni, G. Camussi, R. Romagnoli, Extracellular Vesicles from Human Liver Stem Cells Reduce Injury in an Ex Vivo Normothermic Hypoxic Rat Liver Perfusion Model, Transplantation. 102 (2018) e205-e210. https://doi.org/10.1097/tp.0000000000002123.

[96] C. Grange, S. Tritta, M. Tapparo, M. Cedrino, C. Tetta, G. Camussi, M.F. Brizzi, Stem cellderived extracellular vesicles inhibit and revert fibrosis progression in a mouse model of diabetic nephropathy, Sci. Rep. 9 (2019) 4468. https://doi.org/10.1038/s41598-019-41100-9.

[97] A. Gualerzi, S.A.A. Kooijmans, S. Niada, S. Picciolini, A.T. Brini, G. Camussi, M. Bedoni, Raman spectroscopy as a quick tool to assess purity of extracellular vesicle preparations and predict their functionality, J. Extracell. Vesicles. 8 (2019) 1568780. 
https://doi.org/10.1080/20013078.2019.1568780.

[98] M.C. Deregibus, F. Figliolini, S. D’Antico, P.M. Manzini, C. Pasquino, M. De Lena, C. Tetta, M.F. Brizzi, G. Camussi, Charge-based precipitation of extracellular vesicles., Int. J. Mol. Med. 38 (2016) 1359-1366. https://doi.org/10.3892/ijmm.2016.2759.

[99] N. Ichinohe, M. Ishii, N. Tanimizu, J. Kon, Y. Yoshioka, T. Ochiya, T. Mizuguchi, K. Hirata, T. Mitaka, Transplantation of Thy 1 + Cells Accelerates Liver Regeneration by Enhancing the Growth of Small Hepatocyte-Like Progenitor Cells via IL17RB Signaling, Stem Cells. 35 (2017) 920-931. https://doi.org/10.1002/stem.2548.

[100] V. Abbate, M. Marcantoni, F. Giuliante, F.M. Vecchio, I. Gatto, C. Mele, A. Saviano, D. Arciuolo, E. Gaetani, M.C. Ferrari, I. Giarretta, F. Ardito, L. Riccardi, A. Nicoletti, F.R. Ponziani, A. Gasbarrini, M. Pompili, R. Pola, HepPar1-Positive Circulating Microparticles Are Increased in Subjects with Hepatocellular Carcinoma and Predict Early Recurrence after Liver Resection., Int. J. Mol. Sci. 18 (2017). https://doi.org/10.3390/ijms18051043.

[101] A. Arbelaiz, M. Azkargorta, M. Krawczyk, A. Santos-Laso, A. Lapitz, M.J. Perugorria, O. Erice, E. Gonzalez, R. Jimenez-Agüero, A. Lacasta, C. Ibarra, A. Sanchez-Campos, J.P. Jimeno, F. Lammert, P. Milkiewicz, M. Marzioni, R.I.R. Macias, J.J.G. Marin, T. Patel, G.J. Gores, I. Martinez, F. Elortza, J.M. Falcon-Perez, L. Bujanda, J.M. Banales, Serum extracellular vesicles contain protein biomarkers for primary sclerosing cholangitis and cholangiocarcinoma, Hepatology. 66 (2017) 1125-1143. https://doi.org/10.1002/hep.29291.

[102] M. Eldh, R. Olofsson Bagge, C. Lässer, J. Svanvik, M. Sjöstrand, J. Mattsson, P. Lindnér, D.-S. Choi, Y.S. Gho, J. Lötvall, MicroRNA in exosomes isolated directly from the liver circulation in patients with metastatic uveal melanoma, BMC Cancer. 14 (2014) 962. https://doi.org/10.1186/1471-2407-14-962.

[103] T. Fang, H. Lv, G. Lv, T. Li, C. Wang, Q. Han, L. Yu, B. Su, L. Guo, S. Huang, D. Cao, L. Tang, S. Tang, M. Wu, W. Yang, H. Wang, Tumor-derived exosomal miR-1247-3p induces cancerassociated fibroblast activation to foster lung metastasis of liver cancer., Nat. Commun. 9 (2018) 191. https://doi.org/10.1038/s41467-017-02583-0.

[104] F. Fornari, M. Ferracin, D. Trerè, M. Milazzo, S. Marinelli, M. Galassi, L. Venerandi, D. Pollutri, C. Patrizi, A. Borghi, F.G. Foschi, G.F. Stefanini, M. Negrini, L. Bolondi, L. Gramantieri, Circulating microRNAs, miR-939, miR-595, miR-519d and miR-494, Identify Cirrhotic Patients with HCC., PLoS One. 10 (2015) e0141448. https://doi.org/10.1371/journal.pone.0141448.

[105] Q. Fu, Q. Zhang, Y. Lou, J. Yang, G. Nie, Q. Chen, Y. Chen, J. Zhang, J. Wang, T. Wei, H. Qin, X. Dang, X. Bai, T. Liang, Primary tumor-derived exosomes facilitate metastasis by regulating adhesion of circulating tumor cells via SMAD3 in liver cancer, Oncogene. 37 (2018) 6105-6118. https://doi.org/10.1038/s41388-018-0391-0.

[106] N.S. Holman, M. Mosedale, K.K. Wolf, E.L. LeCluyse, P.B. Watkins, Subtoxic alterations in hepatocyte-derived exosomes: An early step in drug-induced liver injury?, Toxicol. Sci. 151 (2016) 365-375. https://doi.org/10.1093/toxsci/kfw047.

[107] C. Jiao, X. Jiao, A. Zhu, J. Ge, X. Xu, Exosomal miR-34s panel as potential novel diagnostic and prognostic biomarker in patients with hepatoblastoma, J. Pediatr. Surg. 52 (2017) 618624. https://doi.org/10.1016/J.JPEDSURG.2016.09.070. 
[108] X. Jiao, Z. Fan, H. Chen, P. He, Y. Li, Q. Zhang, C. Ke, Serum and exosomal miR-122 and miR-199a as a biomarker to predict therapeutic efficacy of hepatitis $C$ patients, J. Med. Virol. 89 (2017) 1597-1605. https://doi.org/10.1002/jmv.24829.

[109] M. Kornek, M. Lynch, S.H. Mehta, M. Lai, M. Exley, N.H. Afdhal, D. Schuppan, Circulating Microparticles as Disease-Specific Biomarkers of Severity of Inflammation in Patients With Hepatitis C or Nonalcoholic Steatohepatitis, Gastroenterology. 143 (2012) 448-458. https://doi.org/10.1053/J.GASTRO.2012.04.031.

[110] M. Kornek, Y. Popov, T.A. Libermann, N.H. Afdhal, D. Schuppan, Human T cell microparticles circulate in blood of hepatitis patients and induce fibrolytic activation of hepatic stellate cells, Hepatology. 53 (2011) 230-242. https://doi.org/10.1002/hep.23999.

[111] E. Kostallari, P. Hirsova, A. Prasnicka, V.K. Verma, U. Yaqoob, N. Wongjarupong, L.R. Roberts, V.H. Shah, Hepatic stellate cell-derived platelet-derived growth factor receptor-alphaenriched extracellular vesicles promote liver fibrosis in mice through SHP2, Hepatology. 68 (2018) 333-348. https://doi.org/10.1002/hep.29803.

[112] Y. Banz, G.-M. Item, A. Vogt, R. Rieben, D. Candinas, G. Beldi, Endothelial- and PlateletDerived Microparticles Are Generated During Liver Resection in Humans, J. Investig. Surg. 29 (2016) 20-31. https://doi.org/10.3109/08941939.2015.1047540.

[113] J. Lambrecht, P.J. Poortmans, S. Verhulst, H. Reynaert, I. Mannaerts, L.A. van Grunsven, Circulating ECV-Associated miRNAs as Potential Clinical Biomarkers in Early Stage HBV and HCV Induced Liver Fibrosis, Front. Pharmacol. 8 (2017) 56. https://doi.org/10.3389/FPHAR.2017.00056.

[114] B. Li, R. Mao, C. Liu, W. Zhang, Y. Tang, Z. Guo, LncRNA FAL1 promotes cell proliferation and migration by acting as a CeRNA of miR-1236 in hepatocellular carcinoma cells, Life Sci. 197 (2018) 122-129. https://doi.org/10.1016/J.LFS.2018.02.006.

[115] J. Li, K. Liu, Y. Liu, Y. Xu, F. Zhang, H. Yang, J. Liu, T. Pan, J. Chen, M. Wu, X. Zhou, Z. Yuan, Exosomes mediate the cell-to-cell transmission of IFN-\$a\$-induced antiviral activity, Nat. Immunol. 14 (2013) 793-803. https://doi.org/10.1038/ni.2647.

[116] X. Li, R. Liu, Z. Huang, E.C. Gurley, X. Wang, J. Wang, H. He, H. Yang, G. Lai, L. Zhang, J.S. Bajaj, M. White, W.M. Pandak, P.B. Hylemon, H. Zhou, Cholangiocyte-derived exosomal long noncoding RNA H19 promotes cholestatic liver injury in mouse and humans, Hepatology. 68 (2018) 599-615. https://doi.org/10.1002/hep.29838.

[117] Y.I. LI, G.-M. XIANG, L.-L. LIU, C. LIU, F.E.I. LIU, D.-N. JIANG, X.-Y. PU, Assessment of endogenous reference gene suitability for serum exosomal microRNA expression analysis in liver carcinoma resection studies, Mol. Med. Rep. 12 (2015) 4683-4691. https://doi.org/10.3892/mmr.2015.3919.

[118] Y. Li, L. Zhang, F. Liu, G. Xiang, D. Jiang, X. Pu, Identification of Endogenous Controls for Analyzing Serum Exosomal miRNA in Patients with Hepatitis B or Hepatocellular Carcinoma, Dis. Markers. 2015 (2015) 1-12. https://doi.org/10.1155/2015/893594.

[119] Y. Li, L. Zhang, F. Liu, G. Xiang, D. Jiang, X. Pu, Identification of endogenous controls for analyzing serum exosomal miRNA in patients with hepatitis $B$ or hepatocellular carcinoma., Dis. Markers. 2015 (2015) 893594. https://doi.org/10.1155/2015/893594. 
[120] W. Liu, S. Chen, B. Liu, Diagnostic and prognostic values of serum exosomal microRNA-21 in children with hepatoblastoma: a Chinese population-based study, Pediatr. Surg. Int. 32 (2016) 1059-1065. https://doi.org/10.1007/s00383-016-3960-8.

[121] L. Lu, D. Guo, X. Chen, W. Xiong, S. Jie, H. Li, Abnormal miRNAs Targeting Chromosome Open Reading Frame Genes were Enriched in Microvesicles Derived from the Circulation of HCC, Biochem. Genet. 54 (2016) 120-133. https://doi.org/10.1007/s10528-015-9705-x.

[122] S. Mastoridis, G.M. Bertolino, G. Whitehouse, F. Dazzi, A. Sanchez-Fueyo, M. MartinezLlordella, Multiparametric Analysis of Circulating Exosomes and Other Small Extracellular Vesicles by Advanced Imaging Flow Cytometry., Front. Immunol. 9 (2018) 1583. https://doi.org/10.3389/fimmu.2018.01583.

[123] E. Brandon-Warner, N.A. Feilen, C.R. Culberson, C.O. Field, A.S. DeLemos, M.W. Russo, L.W. Schrum, Processing of miR17-92 Cluster in Hepatic Stellate Cells Promotes Hepatic Fibrogenesis During Alcohol-Induced Injury, Alcohol. Clin. Exp. Res. 40 (2016) 1430-1442. https://doi.org/10.1111/acer.13116.

[124] K. Matsuura, V. De Giorgi, C. Schechterly, R.Y. Wang, P. Farci, Y. Tanaka, H.J. Alter, Circulating let-7 levels in plasma and extracellular vesicles correlate with hepatic fibrosis progression in chronic hepatitis C, Hepatology. 64 (2016) 732-745. https://doi.org/10.1002/hep.28660.

[125] F. Momen-Heravi, B. Saha, K. Kodys, D. Catalano, A. Satishchandran, G. Szabo, Increased number of circulating exosomes and their microRNA cargos are potential novel biomarkers in alcoholic hepatitis, J. Transl. Med. 13 (2015) 1-13. https://doi.org/10.1186/s12967-015-0623-9.

[126] D.D. Murray, K. Suzuki, M. Law, J. Trebicka, J.N. Nordwall, M. Johnson, M.J. Vjecha, A.D. Kelleher, S. Emery, Circulating miR-122 and miR-200a as biomarkers for fatal liver disease in ART-treated, HIV-1-infected individuals, Sci. Rep. 7 (2017) 10934. https://doi.org/10.1038/S41598-017-11405-8.

[127] A. Payancé, G. Silva-Junior, J. Bissonnette, M. Tanguy, B. Pasquet, C. Levi, O. Roux, O. Nekachtali, A. Baiges, V. Hernández-Gea, C. Laouénan, D. Lebrec, M. Albuquerque, V. Paradis, R. Moreau, D. Valla, F. Durand, C.M. Boulanger, J. Garcia-Pagan, P. Rautou, Hepatocyte microvesicle levels improve prediction of mortality in patients with cirrhosis, Hepatology. 68 (2018) 1508-1518. https://doi.org/10.1002/hep.29903.

[128] C. Pu, H. Huang, Z. Wang, W. Zou, Y. Lv, Z. Zhou, Q. Zhang, L. Qiao, F. Wu, S. Shao, Extracellular Vesicle-Associated mir-21 and mir-144 Are Markedly Elevated in Serum of Patients With Hepatocellular Carcinoma., Front. Physiol. 9 (2018) 930. https://doi.org/10.3389/fphys.2018.00930.

[129] P. Rautou, J. Bresson, Y. Sainte-Marie, A. Vion, V. Paradis, J. Renard, C. Devue, C. Heymes, P. Letteron, L. Elkrief, D. Lebrec, D. Valla, A. Tedgui, R. Moreau, C.M. Boulanger, Abnormal Plasma Microparticles Impair Vasoconstrictor Responses in Patients With Cirrhosis, Gastroenterology. 143 (2012) 166--176.e6. https://doi.org/10.1053/J.GASTRO.2012.03.040.

[130] P.-E. Rautou, A.-C. Vion, J.P. Luyendyk, N. Mackman, Circulating microparticle tissue factor activity is increased in patients with cirrhosis., Hepatology. 60 (2014) 1793-1795. 
https://doi.org/10.1002/hep.27033.

[131] G. Rega-Kaun, D. Ritzel, C. Kaun, B. Ebenbauer, B. Thaler, M. Prager, S. Demyanets, J. Wojta, P.J. Hohensinner, G. Rega-Kaun, D. Ritzel, C. Kaun, B. Ebenbauer, B. Thaler, M. Prager, S. Demyanets, J. Wojta, P.J. Hohensinner, Changes of Circulating Extracellular Vesicles from the Liver after Roux-en-Y Bariatric Surgery, Int. J. Mol. Sci. 20 (2019) 2153. https://doi.org/10.3390/ijms20092153.

[132] B. Saha, F. Momen-Heravi, K. Kodys, G. Szabo, MicroRNA Cargo of Extracellular Vesicles from Alcohol-exposed Monocytes Signals Naive Monocytes to Differentiate into M2 Macrophages., J. Biol. Chem. 291 (2016) 149-159. https://doi.org/10.1074/jbc.M115.694133.

[133] L. Santangelo, V. Bordoni, C. Montaldo, E. Cimini, A. Zingoni, C. Battistelli, G. D'Offizi, M.R. Capobianchi, A. Santoni, M. Tripodi, C. Agrati, Hepatitis C virus direct-acting antivirals therapy impacts on extracellular vesicles microRNAs content and on their immunomodulating properties, Liver Int. 38 (2018) 1741-1750. https://doi.org/10.1111/liv.13700.

[134] S. V Brodsky, M.E. Facciuto, D. Heydt, J. Chen, H.K. Islam, M. Kajstura, G. Ramaswamy, M. Aguero-Rosenfeld, Dynamics of circulating microparticles in liver transplant patients., J. Gastrointestin. Liver Dis. 17 (2008) 261-268. http://www.ncbi.nlm.nih.gov/pubmed/18836617.

[135] M. Shi, Y. Jiang, L. Yang, S. Yan, Y.-G. Wang, X.-J. Lu, Decreased levels of serum exosomal miR-638 predict poor prognosis in hepatocellular carcinoma, J. Cell. Biochem. 119 (2018) 4711-4716. https://doi.org/10.1002/jcb.26650.

[136] W. Sohn, J. Kim, S.H. Kang, S.R. Yang, J.-Y. Cho, H.C. Cho, S.G. Shim, Y.-H. Paik, Serum exosomal microRNAs as novel biomarkers for hepatocellular carcinoma, Exp. Mol. Med. 47 (2015) e184. https://doi.org/10.1038/EMM.2015.68.

[137] R.T. Stravitz, R. Bowling, R.L. Bradford, N.S. Key, S. Glover, L.R. Thacker, D.A. Gabriel, Role of procoagulant microparticles in mediating complications and outcome of acute liver injury/acute liver failure., Hepatology. 58 (2013) 304-313. https://doi.org/10.1002/hep.26307.

[138] K. Sugimachi, T. Matsumura, H. Hirata, R. Uchi, M. Ueda, H. Ueo, Y. Shinden, T. Iguchi, H. Eguchi, K. Shirabe, T. Ochiya, Y. Maehara, K. Mimori, Identification of a bona fide microRNA biomarker in serum exosomes that predicts hepatocellular carcinoma recurrence after liver transplantation., Br. J. Cancer. 112 (2015) 532-538. https://doi.org/10.1038/bjc.2014.621.

[139] S. Sukriti, M.C. Choudhary, J.S. Maras, S. Sharma, S. Thangariyal, A. Singh, S. Das, M. Islam, S. Sharma, N. Trehanpati, E. Gupta, S.K. Sarin, Extracellular vesicles from hepatitis B patients serve as reservoir of hepatitis B virus DNA, J. Viral Hepat. 26 (2019) 211-214. https://doi.org/10.1111/jvh.12995.

[140] R.S.Z. Taleb, P. Moez, D. Younan, M. Eisenacher, M. Tenbusch, B. Sitek, T. Bracht, Quantitative proteome analysis of plasma microparticles for the characterization of HCVinduced hepatic cirrhosis and hepatocellular carcinoma, PROTEOMICS - Clin. Appl. 11 (2017) 1700014. https://doi.org/10.1002/prca.201700014.

[141] T. Tomiyama, G.-X. Yang, M. Zhao, W. Zhang, H. Tanaka, J. Wang, P.S.C. Leung, K. Okazaki, X.-S. He, Q. Lu, R.L. Coppel, C.L. Bowlus, M.E. Gershwin, The modulation of co-stimulatory molecules by circulating exosomes in primary biliary cirrhosis, Cell. Mol. Immunol. 14 (2017) 276. https://doi.org/10.1038/CMI.2015.86. 
[142] H. Wang, L. Hou, A. Li, Y. Duan, H. Gao, X. Song, Expression of serum exosomal microRNA21 in human hepatocellular carcinoma., Biomed Res. Int. 2014 (2014) 864894. https://doi.org/10.1155/2014/864894.

[143] W. Wang, H. Li, Y. Zhou, S. Jie, Peripheral blood microvesicles are potential biomarkers for hepatocellular carcinoma, Cancer Biomarkers. 13 (2013) 351-357. https://doi.org/10.3233/CBM-130370.

[144] X. Wang, K.J. Kwak, Z. Yang, A. Zhang, X. Zhang, R. Sullivan, D. Lin, R.L. Lee, C. Castro, K. Ghoshal, C. Schmidt, L.J. Lee, Extracellular mRNA detected by molecular beacons in tethered lipoplex nanoparticles for diagnosis of human hepatocellular carcinoma., PLoS One. 13 (2018) e0198552. https://doi.org/10.1371/journal.pone.0198552.

[145] L. Chen, R. Chen, S. Kemper, M. Cong, H. You, D.R. Brigstock, Therapeutic effects of serum extracellular vesicles in liver fibrosis., J. Extracell. Vesicles. 7 (2018) 1461505. https://doi.org/10.1080/20013078.2018.1461505.

[146] M.-W. Welker, D. Reichert, S. Susser, C. Sarrazin, Y. Martinez, E. Herrmann, S. Zeuzem, A. Piiper, B. Kronenberger, Soluble Serum CD81 Is Elevated in Patients with Chronic Hepatitis C and Correlates with Alanine Aminotransferase Serum Activity, PLoS One. 7 (2012) e30796. https://doi.org/10.1371/journal.pone.0030796.

[147] J.A. Welsh, E. Scorletti, G.F. Clough, N.A. Englyst, C.D. Byrne, Leukocyte extracellular vesicle concentration is inversely associated with liver fibrosis severity in NAFLD, J. Leukoc. Biol. 104 (2018) 631-639. https://doi.org/10.1002/JLB.5A1217-501R.

[148] H. Xu, X. Dong, Y. Chen, X. Wang, Serum exosomal hnRNPH1 mRNA as a novel marker for hepatocellular carcinoma, Clin. Chem. Lab. Med. 56 (2018) 479-484. https://doi.org/10.1515/cclm-2017-0327.

[149] H. Xu, C. Liao, P. Zuo, Z. Liu, B.-C. Ye, Magnetic-Based Microfluidic Device for On-Chip Isolation and Detection of Tumor-Derived Exosomes, Anal. Chem. 90 (2018) 13451-13458. https://doi.org/10.1021/acs.analchem.8b03272.

[150] X. Xue, X. Wang, Y. Zhao, R. Hu, L. Qin, Exosomal miR-93 promotes proliferation and invasion in hepatocellular carcinoma by directly inhibiting TIMP2/TP53INP1/CDKN1A, Biochem. Biophys. Res. Commun. 502 (2018) 515-521. https://doi.org/10.1016/J.BBRC.2018.05.208.

[151] Y. Yang, Q. Han, Z. Hou, C. Zhang, Z. Tian, J. Zhang, Exosomes mediate hepatitis B virus (HBV) transmission and NK-cell dysfunction, Cell. Mol. Immunol. 14 (2017) 465-475. https://doi.org/10.1038/cmi.2016.24.

[152] L.-X. Yu, B.-L. Zhang, Y. Yang, M.-C. Wang, G.-L. Lei, Y. Gao, H. Liu, C.-H. Xiao, J.-J. Xu, H. Qin, X.-Y. Xu, Z.-S. Chen, D.-D. Zhang, F.-G. Li, S.-G. Zhang, R. Liu, Exosomal microRNAs as potential biomarkers for cancer cell migration and prognosis in hepatocellular carcinoma patient-derived cell models., Oncol. Rep. 41 (2019) 257-269. https://doi.org/10.3892/or.2018.6829.

[153] H. Zhang, T. Deng, S. Ge, Y. Liu, M. Bai, K. Zhu, Q. Fan, J. Li, T. Ning, F. Tian, H. Li, W. Sun, G. Ying, Y. Ba, Exosome circRNA secreted from adipocytes promotes the growth of hepatocellular carcinoma by targeting deubiquitination-related USP7, Oncogene. 38 (2019) 2844-2859. https://doi.org/10.1038/s41388-018-0619-z. 
[154] H. Zhang, T. Deng, R. Liu, M. Bai, L. Zhou, X. Wang, S. Li, X. Wang, H. Yang, J. Li, T. Ning, D. Huang, H. Li, L. Zhang, G. Ying, Y. Ba, Exosome-delivered EGFR regulates liver microenvironment to promote gastric cancer liver metastasis., Nat. Commun. 8 (2017) 15016. https://doi.org/10.1038/ncomms15016.

[155] L. Li, D. Masica, M. Ishida, C. Tomuleasa, S. Umegaki, A.N. Kalloo, C. Georgiades, V.K. Singh, M. Khashab, S. Amateau, Z. Li, P. Okolo, A.-M. Lennon, P. Saxena, J.-F. Geschwind, T. Schlachter, K. Hong, T.M. Pawlik, M. Canto, J. Law, R. Sharaiha, C.R. Weiss, P. Thuluvath, M. Goggins, E.J. Shin, H. Peng, V. Kumbhari, S. Hutfless, L. Zhou, E. Mezey, S.J. Meltzer, R. Karchin, F.M. Selaru, Human bile contains microRNA-laden extracellular vesicles that can be used for cholangiocarcinoma diagnosis., Hepatology. 60 (2014) 896-907. https://doi.org/10.1002/hep.27050.

[156] Y. Cho, E. Mezey, J.P. Hardwick, N. Salem, Jr., D.L. Clemens, B. Song, Increased ethanolinducible cytochrome P450-2E1 and cytochrome P450 isoforms in exosomes of alcoholexposed rodents and patients with alcoholism through oxidative and endoplasmic reticulum stress, Hepatol. Commun. 1 (2017) 675. https://doi.org/10.1002/HEP4.1066.

[157] M.C. Deregibus, F. Figliolini, S. D’Antico, P.M. Manzini, C. Pasquino, M. De Lena, C. Tetta, M.F. Brizzi, G. Camussi, Charge-based precipitation of extracellular vesicles., Int. J. Mol. Med. 38 (2016) 1359-1366. https://doi.org/10.3892/ijmm.2016.2759.

[158] L. Duan, A. Ramachandran, J.Y. Akakpo, J.L. Weemhoff, S.C. Curry, H. Jaeschke, Role of extracellular vesicles in release of protein adducts after acetaminophen-induced liver injury in mice and humans, Toxicol. Lett. 301 (2019) 125-132. https://doi.org/10.1016/J.TOXLET.2018.11.005.

[159] A. Eguchi, N. Franz, Y. Kobayashi, M. Iwasa, N. Wagner, F. Hildebrand, Y. Takei, I. Marzi, B. Relja, Circulating Extracellular Vesicles and Their miR "Barcode" Differentiate Alcohol Drinkers With Liver Injury and Those Without Liver Injury in Severe Trauma Patients., Front. Med. 6 (2019) 30. https://doi.org/10.3389/fmed.2019.00030.

[160] M. Eldh, R. Olofsson Bagge, C. Lässer, J. Svanvik, M. Sjöstrand, J. Mattsson, P. Lindnér, D.-S. Choi, Y.S. Gho, J. Lötvall, MicroRNA in exosomes isolated directly from the liver circulation in patients with metastatic uveal melanoma, BMC Cancer. 14 (2014) 962. https://doi.org/10.1186/1471-2407-14-962.

[161] L. Li, D. Masica, M. Ishida, C. Tomuleasa, S. Umegaki, A.N. Kalloo, C. Georgiades, V.K. Singh, M. Khashab, S. Amateau, Z. Li, P. Okolo, A.-M. Lennon, P. Saxena, J.-F. Geschwind, T. Schlachter, K. Hong, T.M. Pawlik, M. Canto, J. Law, R. Sharaiha, C.R. Weiss, P. Thuluvath, M. Goggins, E.J. Shin, H. Peng, V. Kumbhari, S. Hutfless, L. Zhou, E. Mezey, S.J. Meltzer, R. Karchin, F.M. Selaru, Human bile contains MicroRNA-laden extracellular vesicles that can be used for cholangiocarcinoma diagnosis, Hepatology. 60 (2014) 896-907. https://doi.org/10.1002/hep.27050.

[162] Q. Fu, Q. Zhang, Y. Lou, J. Yang, G. Nie, Q. Chen, Y. Chen, J. Zhang, J. Wang, T. Wei, H. Qin, X. Dang, X. Bai, T. Liang, Primary tumor-derived exosomes facilitate metastasis by regulating adhesion of circulating tumor cells via SMAD3 in liver cancer, Oncogene. 37 (2018) 
6105-6118. https://doi.org/10.1038/s41388-018-0391-0.

[163] M. Alhomrani, J. Correia, M. Zavou, B. Leaw, N. Kuk, R. Xu, M.I. Saad, A. Hodge, D.W. Greening, R. Lim, W. Sievert, The Human Amnion Epithelial Cell Secretome Decreases Hepatic Fibrosis in Mice with Chronic Liver Fibrosis, Front. Pharmacol. 8 (2017). https://doi.org/10.3389/FPHAR.2017.00748.

[164] S. Bala, T. Csak, F. Momen-Heravi, D. Lippai, K. Kodys, D. Catalano, A. Satishchandran, V. Ambros, G. Szabo, Biodistribution and function of extracellular miRNA-155 in mice., Sci. Rep. 5 (2015) 10721. https://doi.org/10.1038/srep10721.

[165] S. Bala, J. Petrasek, S. Mundkur, D. Catalano, I. Levin, J. Ward, H. Alao, K. Kodys, G. Szabo, Circulating microRNAs in exosomes indicate hepatocyte injury and inflammation in alcoholic, drug-induced and inflammatory liver diseases, Hepatology. 56 (2012) 1946. https://doi.org/10.1002/HEP.25873.

[166] M. Baron, A.S. Leroyer, Z. Majd, F. Lalloyer, E. Vallez, K. Bantubungi, G. Chinetti-Gbaguidi, P. Delerive, C.M. Boulanger, B. Staels, A. Tailleux, PPARa activation differently affects microparticle content in atherosclerotic lesions and liver of a mouse model of atherosclerosis and NASH, Atherosclerosis. 218 (2011) 69-76. https://doi.org/10.1016/J.ATHEROSCLEROSIS.2011.03.009.

[167] H. Cao, Z. Yue, H. Gao, C. Chen, K. Cui, K. Zhang, Y. Cheng, G. Shao, D. Kong, Z. Li, D. Ding, Y. Wang, In Vivo Real-Time Imaging of Extracellular Vesicles in Liver Regeneration via Aggregation-Induced Emission Luminogens, ACS Nano. 13 (2019) 3522-3533. https://doi.org/10.1021/acsnano.8b09776.

[168] C. Cefaratti, A. Romani, Modulation of $\mathrm{Na}+/ \mathrm{Mg} 2+$ exchanger stoichiometry ratio by $\mathrm{Cl}-$ ions in basolateral rat liver plasma membrane vesicles, Mol. Cell. Biochem. 351 (2011) 133-142. https://doi.org/10.1007/s11010-011-0720-x.

[169] C. Cefaratti, A. Romani, A. Scarpa, Characterization of two $\mathrm{Mg}^{2+}$ transporters in sealed plasma membrane vesicles from rat liver, Am. J. Physiol. Physiol. 275 (1998) C995-C1008. https://doi.org/10.1152/ajpcell.1998.275.4.C995.

[170] J. Chen, Y. Yu, S. Li, Y. Liu, S. Zhou, S. Cao, J. Yin, G. Li, MicroRNA-30a ameliorates hepatic fibrosis by inhibiting Beclin1-mediated autophagy., J. Cell. Mol. Med. 21 (2017) 3679-3692. https://doi.org/10.1111/jcmm.13278.

[171] L. Chen, R. Chen, S. Kemper, M. Cong, H. You, D.R. Brigstock, Therapeutic effects of serum extracellular vesicles in liver fibrosis., J. Extracell. Vesicles. 7 (2018) 1461505. https://doi.org/10.1080/20013078.2018.1461505.

[172] Y. Cho, E. Mezey, J.P. Hardwick, N. Salem, Jr., D.L. Clemens, B. Song, Increased ethanolinducible cytochrome P450-2E1 and cytochrome P450 isoforms in exosomes of alcoholexposed rodents and patients with alcoholism through oxidative and endoplasmic reticulum stress, Hepatol. Commun. 1 (2017) 675. https://doi.org/10.1002/HEP4.1066.

[173] Y.-E. Cho, W. Seo, D.-K. Kim, P.-G. Moon, S.-H. Kim, B.-H. Lee, B.-J. Song, M.-C. Baek, Exogenous exosomes from mice with acetaminophen-induced liver injury promote toxicity in the recipient hepatocytes and mice, Sci. Rep. 8 (2018) 16070. https://doi.org/10.1038/S41598- 
018-34309-7.

[174] J. Conde-Vancells, E. Rodriguez-Suarez, N. Embade, D. Gil, R. Matthiesen, M. Valle, F. Elortza, S.C. Lu, J.M. Mato, J.M. Falcon-Perez, Characterization and comprehensive proteome profiling of exosomes secreted by hepatocytes., J. Proteome Res. 7 (2008) 5157-66. http://www.ncbi.nlm.nih.gov/pubmed/19367702 (accessed May 9, 2019).

[175] T.M. de Assuncao, V.H. Shah, S. Cao, V.K. Verma, Q. Ding, R. Wang, R.C. Huebert, D. Mukhopadhyay, P. Hirsova, U. Yaqoob, Exosome Adherence and Internalization by Hepatic Stellate Cells Triggers Sphingosine 1-Phosphate-dependent Migration, J. Biol. Chem. 290 (2015) 30684-30696. https://doi.org/10.1074/jbc.m115.671735.

[176] S. Dolovcak, S.L. Waldrop, F. Xiao, G. Kilic, Evidence for sustained ATP release from liver cells that is not mediated by vesicular exocytosis, Purinergic Signal. 7 (2011) 435-446. https://doi.org/10.1007/s11302-011-9240-0.

[177] R.J. Epping, F.L. Bygrave, A procedure for the rapid isolation from rat liver of plasma membrane vesicles exhibiting Ca2+-transport and Ca2+-ATPase activities., Biochem. J. 223 (1984) 733-45. https://doi.org/10.1042/bj2230733.

[178] C.M. Freeman, R.C. Quillin, G.C. Wilson, H. Nojima, B.L. Johnson, J.M. Sutton, R.M. Schuster, J. Blanchard, M.J. Edwards, C.C. Caldwell, A.B. Lentsch, C.C. Caldwell, A.B. Lentsch, Characterization of microparticles after hepatic ischemia-reperfusion injury., PLoS One. 9 (2014) e97945. https://doi.org/10.1371/journal.pone.0097945.

[179] N.S. Holman, M. Mosedale, K.K. Wolf, E.L. LeCluyse, P.B. Watkins, Subtoxic alterations in hepatocyte-derived exosomes: An early step in drug-induced liver injury?, Toxicol. Sci. 151 (2016) 365-375. https://doi.org/10.1093/toxsci/kfw047.

[180] S.H. Ibrahim, P. Hirsova, K. Tomita, S.F. Bronk, N.W. Werneburg, S.A. Harrison, V.S. Goodfellow, H. Malhi, G.J. Gores, Mixed lineage kinase 3 mediates release of C-X-C motif ligand 10-bearing chemotactic extracellular vesicles from lipotoxic hepatocytes., Hepatology. 63 (2016) 731-44. https://doi.org/10.1002/hep.28252.

[181] E. Kostallari, P. Hirsova, A. Prasnicka, V.K. Verma, U. Yaqoob, N. Wongjarupong, L.R. Roberts, V.H. Shah, Hepatic stellate cell-derived platelet-derived growth factor receptor-alphaenriched extracellular vesicles promote liver fibrosis in mice through SHP2, Hepatology. 68 (2018) 333-348. https://doi.org/10.1002/hep.29803.

[182] M. Li, Y. Lu, Y. Xu, J. Wang, C. Zhang, Y. Du, L. Wang, L. Li, B. Wang, J. Shen, J. Tang, B. Song, Horizontal transfer of exosomal CXCR4 promotes murine hepatocarcinoma cell migration, invasion and lymphangiogenesis, Gene. 676 (2018) 101-109. https://doi.org/10.1016/J.GENE.2018.07.018.

[183] W. Liu, L. Ren, X. Wang, T. Wang, N. Zhang, Y. Gao, H. Luo, N. Navarro-Alvarez, L. Tang, Combination of exosomes and circulating microRNAs may serve as a promising tumor marker complementary to alpha-fetoprotein for early-stage hepatocellular carcinoma diagnosis in rats, J. Cancer Res. Clin. Oncol. 141 (2015) 1767-1778. https://doi.org/10.1007/s00432-015-19430 .

[184] K.S. McCommis, W.T. Hodges, E.M. Brunt, I. Nalbantoglu, W.G. McDonald, C. Holley, H. Fujiwara, J.E. Schaffer, J.R. Colca, B.N. Finck, Targeting the mitochondrial pyruvate carrier 
attenuates fibrosis in a mouse model of nonalcoholic steatohepatitis., Hepatology. 65 (2017) 1543-1556. https://doi.org/10.1002/hep.29025.

[185] F. Momen-Heravi, B. Saha, K. Kodys, D. Catalano, A. Satishchandran, G. Szabo, Increased number of circulating exosomes and their microRNA cargos are potential novel biomarkers in alcoholic hepatitis, J. Transl. Med. 13 (2015) 1-13. https://doi.org/10.1186/s12967-015-0623-9.

[186] T.K. Motawi, M.R. Mohamed, N.N. Shahin, M.A.M. Ali, M.A. Azzam, Time-course expression profile and diagnostic potential of a miRNA panel in exosomes and total serum in acute liver injury, Int. J. Biochem. Cell Biol. 100 (2018) 11-21.

https://doi.org/10.1016/J.BIOCEL.2018.05.002.

[187] L. Palomo, J.E. Mleczko, M. Azkargorta, J. Conde-Vancells, E. González, F. Elortza, F. Royo, J.M. Falcon-Perez, Abundance of Cytochromes in Hepatic Extracellular Vesicles Is Altered by Drugs Related With Drug-Induced Liver Injury., Hepatol. Commun. 2 (2018) 1064-1079. https://doi.org/10.1002/hep4.1210.

[188] Q. Pan, V. Ramakrishnaiah, S. Henry, S. Fouraschen, P.E. de Ruiter, J. Kwekkeboom, H.W. Tilanus, H.L.A. Janssen, L.J.W. van der Laan, Hepatic cell-to-cell transmission of small silencing RNA can extend the therapeutic reach of RNA interference (RNAi), Gut. 61 (2012) 1330-1339. https://doi.org/10.1136/GUTJNL-2011-300449.

[189] Z. Qu, J. Wu, J. Wu, D. Luo, C. Jiang, Y. Ding, Exosomes derived from HCC cells induce sorafenib resistance in hepatocellular carcinoma both in vivo and in vitro., J. Exp. Clin. Cancer Res. 35 (2016) 159. https://doi.org/10.1186/s13046-016-0430-z.

[190] F. Royo, U. Cossío, A. Ruiz de Angulo, J. Llop, J.M. Falcon-Perez, Modification of the glycosylation of extracellular vesicles alters their biodistribution in mice, Nanoscale. 11 (2019) 1531-1537. https://doi.org/10.1039/C8NR03900C.

[191] F. Royo, D. Gil-Carton, E. Gonzalez, J. Mleczko, L. Palomo, M. Perez-Cormenzana, R. Mayo, C. Alonso, J.M. Falcon-Perez, Differences in the metabolite composition and mechanical properties of extracellular vesicles secreted by hepatic cellular models., J. Extracell. Vesicles. 8 (2019) 1575678. https://doi.org/10.1080/20013078.2019.1575678.

[192] F. Royo, L. Moreno, J. Mleczko, L. Palomo, E. Gonzalez, D. Cabrera, A. Cogolludo, F.P. Vizcaino, S. van-Liempd, J.M. Falcon-Perez, Hepatocyte-secreted extracellular vesicles modify blood metabolome and endothelial function by an arginase-dependent mechanism., Sci. Rep. 7 (2017) 42798. https://doi.org/10.1038/srep42798.

[193] F. Royo, L. Palomo, J. Mleczko, E. Gonzalez, C. Alonso, I. Martínez, M. Pérez-Cormenzana, A. Castro, J.M. Falcon-Perez, Metabolically active extracellular vesicles released from hepatocytes under drug-induced liver-damaging conditions modify serum metabolome and might affect different pathophysiological processes, Eur. J. Pharm. Sci. 98 (2017) 51-57. https://doi.org/10.1016/J.EJPS.2016.10.020.

[194] F. Royo, K. Schlangen, L. Palomo, E. Gonzalez, J. Conde-Vancells, A. Berisa, A.M. Aransay, J.M. Falcon-Perez, Transcriptome of extracellular vesicles released by hepatocytes., PLoS One. 8 (2013) e68693. https://doi.org/10.1371/journal.pone.0068693.

[195] B. Saha, F. Momen-Heravi, I. Furi, K. Kodys, D. Catalano, A. Gangopadhyay, R. Haraszti, A. Satishchandran, A. Iracheta-Vellve, A. Adejumo, S.A. Shaffer, G. Szabo, Extracellular vesicles 
from mice with alcoholic liver disease carry a distinct protein cargo and induce macrophage activation through heat shock protein 90., Hepatology. 67 (2018) 1986-2000.

https://doi.org/10.1002/hep.29732.

[196] M. Schmelzle, K. Splith, L.W. Andersen, M. Kornek, D. Schuppan, C. Jones-Bamman, M. Nowak, V. Toxavidis, S.D. Salhanick, L. Han, J. Schulte am Esch, S. Jonas, M.W. Donnino, S.C. Robson, Increased plasma levels of microparticles expressing CD39 and CD133 in acute liver injury., Transplantation. 95 (2013) 63-9. https://doi.org/10.1097/TP.0b013e318278d3cd.

[197] W. Seo, H.S. Eun, S.Y. Kim, H.-S. Yi, Y.-S. Lee, S.-H. Park, M.-J. Jang, E. Jo, S.C. Kim, Y.-M. Han, K.-G. Park, W.-I. Jeong, Exosome-mediated activation of toll-like receptor 3 in stellate cells stimulates interleukin-17 production by $ү \delta$ T cells in liver fibrosis, Hepatology. 64 (2016) 616-631. https://doi.org/10.1002/hep.28644.

[198] L. Simon, M. López, C. Uribe-Cruz, D.F.P. Vergara, L. Silla, U. Matte, Injured hepatocytereleased microvesicles induce bone marrow-derived mononuclear cells differentiation, Differentiation. 90 (2015) 40-47. https://doi.org/10.1016/J.DIFF.2015.09.001.

[199] H.J. Sips, D. Brown, R. Oonk, L. Orci, Orientation of rat-liver plasma membrane vesicles. A biochemical and ultrastructural study, Biochim. Biophys. Acta - Biomembr. 692 (1982) 447454. https://doi.org/10.1016/0005-2736(82)90396-0.

[200] N. Szostak, F. Royo, A. Rybarczyk, M. Szachniuk, J. Blazewicz, A. del Sol, J.M. Falcon-Perez, Sorting signal targeting mRNA into hepatic extracellular vesicles., RNA Biol. 11 (2014) 836-44. https://doi.org/10.4161/rna.29305.

[201] N.C. Teoh, H. Ajamieh, H.J. Wong, K. Croft, T. Mori, A.C. Allison, G.C. Farrell, Microparticles mediate hepatic ischemia-reperfusion injury and are the targets of Diannexin (ASP8597)., PLoS One. 9 (2014) e104376. https://doi.org/10.1371/journal.pone.0104376.

[202] M.-Q. Yang, Q. Du, J. Goswami, P.R. Varley, B. Chen, R.-H. Wang, A.E. Morelli, D.B. Stolz, T.R. Billiar, J. Li, D.A. Geller, Interferon regulatory factor 1-Rab27a regulated extracellular vesicles promote liver ischemia/reperfusion injury., Hepatology. 67 (2018) 1056-1070. https://doi.org/10.1002/hep.29605.

[203] J. Zhang, W. Shan, T. Jin, G. Wu, X.-X. Xiong, H. Jin, S. Zhu, Propofol exerts antihepatocellular carcinoma by microvesicle-mediated transfer of miR-142-3p from macrophage to cancer cells., J. Transl. Med. 12 (2014) 279. https://doi.org/10.1186/s12967-014-0279-x.

[204] A. Zhukov, U. Hellman, M. Ingelman-Sundberg, Purification and characterization of hepsin from rat liver microsomes, Biochim. Biophys. Acta - Protein Struct. Mol. Enzymol. 1337 (1997) 8595. https://doi.org/10.1016/S0167-4838(96)00152-5.

[205] O. Karaosmanoğlu, S. Banerjee, H. Sivas, Identification of biomarkers associated with partial epithelial to mesenchymal transition in the secretome of slug over-expressing hepatocellular carcinoma cells, Cell. Oncol. 41 (2018) 439-453. https://doi.org/10.1007/s13402-018-0384-6.

[206] X. Zhao, Y. Wu, J. Duan, Y. Ma, Z. Shen, L. Wei, X. Cui, J. Zhang, Y. Xie, J. Liu, Quantitative Proteomic Analysis of Exosome Protein Content Changes Induced by Hepatitis B Virus in Huh7 Cells Using SILAC Labeling and LC-MS/MS, J. Proteome Res. 13 (2014) 5391-5402. https://doi.org/10.1021/pr5008703.

[207] N.R. Kapoor, R. Ahuja, S.K. Shukla, V. Kumar, The HBx protein of hepatitis B virus confers 
resistance against nucleolar stress and anti-cancer drug-induced p53 expression, FEBS Lett. 587 (2013) 1287-1292. https://doi.org/10.1016/J.FEBSLET.2013.03.004.

[208] J. Wei, L. Lv, Y. Wan, Y. Cao, G. Li, H. Lin, R. Zhou, C. Shang, J. Cao, H. He, Q. Han, P. Liu, G. Zhou, J. Min, Vps4A functions as a tumor suppressor by regulating the secretion and uptake of exosomal microRNAs in human hepatoma cells., Hepatology. 61 (2015) 1284-94. https://doi.org/10.1002/hep.27660.

[209] N.S. Holman, M. Mosedale, K.K. Wolf, E.L. LeCluyse, P.B. Watkins, Subtoxic Alterations in Hepatocyte-Derived Exosomes: An Early Step in Drug-Induced Liver Injury?, Toxicol. Sci. 151 (2016) 365-75. https://doi.org/10.1093/toxsci/kfw047.

[210] H. Zhang, T. Deng, R. Liu, M. Bai, L. Zhou, X. Wang, S. Li, X. Wang, H. Yang, J. Li, T. Ning, D. Huang, H. Li, L. Zhang, G. Ying, Y. Ba, Exosome-delivered EGFR regulates liver microenvironment to promote gastric cancer liver metastasis., Nat. Commun. 8 (2017) 15016. https://doi.org/10.1038/ncomms15016.

[211] H. Xu, X. Dong, Y. Chen, X. Wang, Serum exosomal hnRNPH1 mRNA as a novel marker for hepatocellular carcinoma, Clin. Chem. Lab. Med. 56 (2018) 479-484. https://doi.org/10.1515/cclm-2017-0327.

[212] M. Mosedale, J.S. Eaddy, O.J. Trask, N.S. Holman, K.K. Wolf, E. LeCluyse, B.R. Ware, S.R. Khetani, J. Lu, W.J. Brock, S.E. Roth, P.B. Watkins, P.B. Watkins, miR-122 Release in Exosomes Precedes Overt Tolvaptan-Induced Necrosis in a Primary Human Hepatocyte Micropatterned Coculture Model., Toxicol. Sci. 161 (2018) 149-158. https://doi.org/10.1093/toxsci/kfx206.

[213] A. Eguchi, R.G. Lazaro, J. Wang, J. Kim, D. Povero, B. Willliams, S.B. Ho, P. Stärkel, B. Schnabl, L. Ohno-Machado, H. Tsukamoto, A.E. Feldstein, Extracellular vesicles released by hepatocytes from gastric infusion model of alcoholic liver disease contain a MicroRNA barcode that can be detected in blood., Hepatology. 65 (2017) 475-490. https://doi.org/10.1002/hep.28838.

[214] P. Hirsova, S.H. Ibrahim, A. Krishnan, V.K. Verma, S.F. Bronk, N.W. Werneburg, M.R Charlton, V.H. Shah, H. Malhi, G.J. Gores, Lipid-Induced Signaling Causes Release of Inflammatory Extracellular Vesicles From Hepatocytes, Gastroenterology. 150 (2016) 956-967. https://doi.org/10.1053/J.GASTRO.2015.12.037.

[215] H. Wang, S. Tan, J. Dong, J. Zhang, B. Yao, X. Xu, Y. Hao, C. Yu, H. Zhou, L. Zhao, R. Peng, iTRAQ quantitatively proteomic analysis of the hippocampus in a rat model of accumulative microwave-induced cognitive impairment, Environ. Sci. Pollut. Res. (2019). https://doi.org/10.1007/s11356-019-04873-0.

[216] P.B. Devhare, R. Sasaki, S. Shrivastava, A.M. Di Bisceglie, R. Ray, R.B. Ray, ExosomeMediated Intercellular Communication between Hepatitis $C$ Virus-Infected Hepatocytes and Hepatic Stellate Cells., J. Virol. 91 (2017). https://doi.org/10.1128/JVI.02225-16.

[217] S.H. Ibrahim, P. Hirsova, G.J. Gores, Non-alcoholic steatohepatitis pathogenesis: sublethal hepatocyte injury as a driver of liver inflammation., Gut. 67 (2018) 963-972. https://doi.org/10.1136/gutjnl-2017-315691.

[218] T. Kogure, T. Patel, Isolation of Extracellular Nanovesicle MicroRNA from Liver Cancer Cells in 
Culture, in: Humana Press, Totowa, NJ, 2013: pp. 11-18. https://doi.org/10.1007/978-1-62703453-1_2.

[219] Z. Chen, L. Yang, Y. Cui, Y. Zhou, X. Yin, J. Guo, G. Zhang, T. Wang, Q.-Y. He, Cytoskeletoncentric protein transportation by exosomes transforms tumor-favorable macrophages., Oncotarget. 7 (2016) 67387-67402. https://doi.org/10.18632/oncotarget.11794.

[220] A. Arbelaiz, A. Lapitz, M. Krawczyk, Á. Santos-Laso, J.L. Lavin, M.J. Perugorria, R. JimenezAguero, A. Lacasta, C. Ibarra, A. Sanchez-Campos, J.P. Jimeno, E. Gonzalez, F. Lammert, M. Marzioni, R. Macias, J. Marin, T.H. Karlsen, J. Falcon-Perez, A. María Aransay, L. Bujanda, J. Banales, Serum and urine extracellular vesicles contain mRNA biomarkers for primary sclerosing cholangitis (PSC) and cholangiocarcinoma (CCA), J. Hepatol. 68 (2018) S435. https://doi.org/10.1016/s0168-8278(18)31109-7.

[221] W. Sohn, J. Kim, S.H. Kang, S.R. Yang, J.-Y. Cho, H.C. Cho, S.G. Shim, Y.-H. Paik, Serum exosomal microRNAs as novel biomarkers for hepatocellular carcinoma, Exp. Mol. Med. 47 (2015) e184. https://doi.org/10.1038/EMM.2015.68.

[222] K. Si-Tayeb, F.P. Lemaigre, S.A. Duncan, Organogenesis and Development of the Liver, Dev. Cell. 18 (2010) 175-189. https://doi.org/10.1016/J.DEVCEL.2010.01.011.

[223] E.R. Anderson, Y.M. Shah, Iron Homeostasis in the Liver, in: Compr. Physiol., John Wiley \& Sons, Inc., Hoboken, NJ, USA, 2013: pp. 315-330. https://doi.org/10.1002/cphy.c120016.

[224] A. Treyer, A. Müsch, Hepatocyte Polarity, in: Compr. Physiol., John Wiley \& Sons, Inc., Hoboken, NJ, USA, 2013: pp. 243-287. https://doi.org/10.1002/cphy.c120009.

[225] F. Royo, J.M. Falcon-Perez, Liver extracellular vesicles in health and disease, J. Extracell. Vesicles. 1 (2012) 18825. https://doi.org/10.3402/jev.v1i0.18825.

[226] M.L. Ruiz, A.D. Mottino, V.A. Catania, M. Vore, Hormonal Regulation of Hepatic Drug Biotransformation and Transport Systems, in: Compr. Physiol., John Wiley \& Sons, Inc., Hoboken, NJ, USA, 2013: pp. 1721-1740. https://doi.org/10.1002/cphy.c130018.

[227] S.A. Mao, J.M. Glorioso, S.L. Nyberg, Liver regeneration, Transl. Res. 163 (2014) 352-362. https://doi.org/10.1016/J.TRSL.2014.01.005.

[228] M.-J. Wang, F. Chen, J.T.Y. Lau, Y.-P. Hu, Hepatocyte polyploidization and its association with pathophysiological processes., Cell Death Dis. 8 (2017) e2805. https://doi.org/10.1038/cddis.2017.167.

[229] G.V. Shelke, C. Lässer, Y.S. Gho, J. Lötvall, Importance of exosome depletion protocols to eliminate functional and RNA-containing extracellular vesicles from fetal bovine serum, J. Extracell. Vesicles. 3 (2014) 24783. https://doi.org/10.3402/jev.v3.24783.

[230] C. Lässer, M. Eldh, J. Lötvall, Isolation and characterization of RNA-containing exosomes., J. Vis. Exp. (2012) e3037. https://doi.org/10.3791/3037.

[231] J. Caradec, G. Kharmate, E. Hosseini-Beheshti, H. Adomat, M. Gleave, E. Guns, Reproducibility and efficiency of serum-derived exosome extraction methods, Clin. Biochem. 47 (2014) 1286-1292. https://doi.org/10.1016/J.CLINBIOCHEM.2014.06.011.

[232] J. Van Deun, P. Mestdagh, R. Sormunen, V. Cocquyt, K. Vermaelen, J. Vandesompele, M. Bracke, O. De Wever, A. Hendrix, The impact of disparate isolation methods for extracellular vesicles on downstream RNA profiling, J. Extracell. Vesicles. 3 (2014) 24858. 
https://doi.org/10.3402/jev.v3.24858.

[233] Y.-T. Tang, Y.-Y. Huang, L. Zheng, S.-H. Qin, X.-P. Xu, T.-X. An, Y. Xu, Y.-S. Wu, X.-M. Hu, B.-H. Ping, Q. Wang, Comparison of isolation methods of exosomes and exosomal RNA from cell culture medium and serum, Int. J. Mol. Med. 40 (2017) 834-844.

https://doi.org/10.3892/ijmm.2017.3080.

[234] Y.S. Lee, S.Y. Kim, E. Ko, J.H. Lee, H.S. Yi, Y.J. Yoo, J. Je, S.J. Suh, Y.K. Jung, J.H. Kim, Y.S. Seo, H.J. Yim, W. II Jeong, J.E. Yeon, S.H. Um, K.S. Byun, Exosomes derived from palmitic acid-treated hepatocytes induce fibrotic activation of hepatic stellate cells, Sci. Rep. (2017). https://doi.org/10.1038/s41598-017-03389-2.

[235] D. Maiolo, L. Paolini, G. Di Noto, A. Zendrini, D. Berti, P. Bergese, D. Ricotta, Colorimetric Nanoplasmonic Assay To Determine Purity and Titrate Extracellular Vesicles, Anal. Chem. 87 (2015) 4168-4176. https://doi.org/10.1021/ac504861d.

[236] A.F. Saleh, E. Lázaro-Ibáñez, M.A.-M. Forsgard, O. Shatnyeva, X. Osteikoetxea, F. Karlsson, N. Heath, M. Ingelsten, J. Rose, J. Harris, M. Mairesse, S.M. Bates, M. Clausen, D. Etal, E. Leonard, M.D. Fellows, N. Dekker, N. Edmunds, Extracellular vesicles induce minimal hepatotoxicity and immunogenicity, Nanoscale. 11 (2019) 6990-7001. https://doi.org/10.1039/C8NR08720B.

[237] N. Dioufa, A.M. Clark, B. Ma, C.H. Beckwitt, A. Wells, Bi-directional exosome-driven intercommunication between the hepatic niche and cancer cells, Mol. Cancer. 16 (2017) 172. https://doi.org/10.1186/s12943-017-0740-6.

[238] H. Senoo, Y. Mezaki, M. Fujiwara, The stellate cell system (vitamin A-storing cell system), Anat. Sci. Int. 92 (2017) 387-455. https://doi.org/10.1007/s12565-017-0395-9.

[239] R. Bataller, D.A. Brenner, Liver fibrosis, J. Clin. Invest. 115 (2005) 209-218. https://doi.org/10.1172/JCl24282.

[240] J.E. Puche, Y. Saiman, S.L. Friedman, Hepatic Stellate Cells and Liver Fibrosis, in: Compr. Physiol., John Wiley \& Sons, Inc., Hoboken, NJ, USA, 2013: pp. 1473-1492. https://doi.org/10.1002/cphy.c120035.

[241] G. Valentino, C. Zivko, F. Weber, L. Brülisauer, P. Luciani, Synergy of phospholipid-drug formulations significantly deactivates pro-fibrogenic human hepatic stellate cells, Pharmaceutics. 11 (2019) 676. https://doi.org/10.3390/pharmaceutics11120676.

[242] L. Xu, A.Y. Hui, E. Albanis, M.J. Arthur, S.M. O'Byrne, W.S. Blaner, P. Mukherjee, S.L. Friedman, F.J. Eng, Human hepatic stellate cell lines, LX-1 and LX-2: new tools for analysis of hepatic fibrosis., Gut. 54 (2005) 142-51. https://doi.org/10.1136/gut.2004.042127.

[243] F. Wang, L. Li, K. Piontek, M. Sakaguchi, F.M. Selaru, Exosome miR-335 as a novel therapeutic strategy in hepatocellular carcinoma., Hepatology. 67 (2018) 940-954. https://doi.org/10.1002/hep.29586.

[244] C. Théry, S. Amigorena, G. Raposo, A. Clayton, Isolation and Characterization of Exosomes from Cell Culture Supernatants and Biological Fluids, Curr. Protoc. Cell Biol. 30 (2006) 3.22.13.22.29. https://doi.org/10.1002/0471143030.cb0322s30.

[245] L. Lu, D. Guo, X. Chen, W. Xiong, S. Jie, H. Li, Abnormal miRNAs Targeting Chromosome Open Reading Frame Genes were Enriched in Microvesicles Derived from the Circulation of 
HCC, Biochem. Genet. 54 (2016) 120-133. https://doi.org/10.1007/s10528-015-9705-x.

[246] C. Théry, Exosomes: Secreted vesicles and intercellular communications, F1000 Biol. Rep. 3 (2011) 1-8. https://doi.org/10.3410/B3-15.

[247] J.H. Tabibian, A.I. Masyuk, T. V. Masyuk, S.P. O'Hara, N.F. LaRusso, Physiology of cholangiocytes, Compr. Physiol. 3 (2013) 541-565. https://doi.org/10.1002/cphy.c120019.

[248] A.F. Hofmann, Enterohepatic Circulation of Bile Acids, in: Compr. Physiol., John Wiley \& Sons, Inc., Hoboken, NJ, USA, 2011: pp. 567-596. https://doi.org/10.1002/cphy.cp060329.

[249] J.L. Boyer, Bile Formation and Secretion, in: Compr. Physiol., John Wiley \& Sons, Inc., Hoboken, NJ, USA, 2013: pp. 1035-1078. https://doi.org/10.1002/cphy.c120027.

[250] L. Maroni, B. Haibo, D. Ray, T. Zhou, Y. Wan, F. Meng, M. Marzioni, G. Alpini, Functional and Structural Features of Cholangiocytes in Health and Disease, Cmgh. 1 (2015) 368-380. https://doi.org/10.1016/j.jcmgh.2015.05.005.

[251] A. Lleo, S. Marzorati, J.-M. Anaya, M.E. Gershwin, Primary biliary cholangitis: a comprehensive overview, Hepatol. Int. 11 (2017) 485-499. https://doi.org/10.1007/s12072-017-9830-1.

[252] T.H. Karlsen, T. Folseraas, D. Thorburn, M. Vesterhus, Primary sclerosing cholangitis -a comprehensive review, J. Hepatol. 67 (2017) 1298-1323.

https://doi.org/10.1016/J.JHEP.2017.07.022.

[253] K. Elvevold, B. Smedsrød, I. Martinez, The liver sinusoidal endothelial cell: A cell type of controversial and confusing identity, Am. J. Physiol. - Gastrointest. Liver Physiol. 294 (2008). https://doi.org/10.1152/ajpgi.00167.2007.

[254] K.K. Sørensen, J. Simon-Santamaria, R.S. McCuskey, B. Smedsrød, Liver Sinusoidal Endothelial Cells, in: Compr. Physiol., John Wiley \& Sons, Inc., Hoboken, NJ, USA, 2015: pp. 1751-1774. https://doi.org/10.1002/cphy.c140078.

[255] R. Wang, Q. Ding, U. Yaqoob, T.M. de Assuncao, V.K. Verma, P. Hirsova, S. Cao, D. Mukhopadhyay, R.C. Huebert, V.H. Shah, Exosome Adherence and Internalization by Hepatic Stellate Cells Triggers Sphingosine 1-Phosphate-dependent Migration., J. Biol. Chem. 290 (2015) 30684-96. https://doi.org/10.1074/jbc.M115.671735.

[256] R.C. Huebert, K. Jagavelu, A.F. Liebl, B.Q. Huang, L. Patrick, N.F. Larusso, R.A. Urrutia, V.H. Shah, Immortalized Liver Endothelial Cells: A Cell Culture Model for Studies of Motility and Angiogenesis, Lab Investig. 90 (2010) 1770-1781. https://doi.org/10.1038/labinvest.2010.132.Immortalized.

[257] K. Tu, J. Li, V.K. Verma, C. Liu, D.D. Billadeau, G. Lamprecht, X. Xiang, L. Guo, R. Dhanasekaran, L.R. Roberts, V.H. Shah, N. Kang, Vasodilator-stimulated phosphoprotein promotes activation of hepatic stellate cells by regulating Rab11-dependent plasma membrane targeting of transforming growth factor beta receptors, Hepatology. 61 (2015) 361-374. https://doi.org/10.1002/hep.27251.

[258] L.J. Dixon, M. Barnes, H. Tang, M.T. Pritchard, L.E. Nagy, Kupffer Cells in the Liver, in: Compr. Physiol., John Wiley \& Sons, Inc., Hoboken, NJ, USA, 2013: pp. 785-797. https://doi.org/10.1002/cphy.c120026.

[259] C. Ju, F. Tacke, Hepatic macrophages in homeostasis and liver diseases: From pathogenesis to novel therapeutic strategies, Cell. Mol. Immunol. 13 (2016) 316-327. 
https://doi.org/10.1038/cmi.2015.104.

[260] A.T. Nguyen-Lefebvre, A. Horuzsko, Kupffer Cell Metabolism and Function., J. Enzymol. Metab. 1 (2015). http://www.ncbi.nlm.nih.gov/pubmed/26937490 (accessed August 26, 2019).

[261] D.P. Bogdanos, B. Gao, M.E. Gershwin, Liver Immunology, in: Compr. Physiol., John Wiley \& Sons, Inc., Hoboken, NJ, USA, 2013: pp. 567-598. https://doi.org/10.1002/cphy.c120011.

[262] M. Hristov, W. Erl, S. Linder, P.C. Weber, J. Sampol, F. Dignat-George, Apoptotic bodies from endothelial cells enhance the number and initiate the differentiation of human endothelial progenitor cells in vitro., Blood. 104 (2004) 2761-6. https://doi.org/10.1182/blood-2003-103614

[263] M. Mittelbrunn, C. Gutiérrez-Vázquez, C. Villarroya-Beltri, S. González, F. Sánchez-Cabo, M.Á. González, A. Bernad, F. Sánchez-Madrid, Unidirectional transfer of microRNA-loaded exosomes from T cells to antigen-presenting cells, Nat. Commun. 2 (2011). https://doi.org/10.1038/ncomms1285.

[264] M.R. Alison, P. Vig, F. Russo, B.W. Bigger, E. Amofah, M. Themis, S. Forbes, Hepatic stem cells: from inside and outside the liver?, Cell Prolif. 37 (2004) 1-21. https://doi.org/10.1111/j.1365-2184.2004.00297.x.

[265] N. Fausto, J.S. Campbell, The role of hepatocytes and oval cells in liver regeneration and repopulation, Mech. Dev. 120 (2003) 117-130. https://doi.org/10.1016/S0925-4773(02)003386.

[266] R.P. Evarts, P. Nagy, H. Nakatsukasa, E. Marsden, S.S. Thorgeirsson, In vivo differentiation of rat liver oval cells into hepatocytes., Cancer Res. 49 (1989) 1541-7. http://www.ncbi.nlm.nih.gov/pubmed/2466557 (accessed September 1, 2019).

[267] N. Shiojiri, J.M. Lemire, N. Fausto, Cell lineages and oval cell progenitors in rat liver development., Cancer Res. 51 (1991) 2611-20. http://www.ncbi.nlm.nih.gov/pubmed/1708696 (accessed September 22, 2019).

[268] T. Mitaka, M. Mikami, G.L. Sattler, H.C. Pitot, Y. Mochizuki, Small cell colonies appear in the primary culture of adult rat hepatocytes in the presence of nicotinamide and epidermal growth factor, Hepatology. 16 (1992) 440-447. https://doi.org/10.1002/hep.1840160224.

[269] J. Kon, H. Ooe, H. Oshima, Y. Kikkawa, T. Mitaka, Expression of CD44 in rat hepatic progenitor cells, J. Hepatol. 45 (2006) 90-98. https://doi.org/10.1016/J.JHEP.2006.01.029.

[270] K. Sasaki, J. Kon, T. Mizuguchi, Q. Chen, H. Ooe, H. Oshima, K. Hirata, T. Mitaka, Proliferation of Hepatocyte Progenitor Cells Isolated from Adult Human Livers in Serum-Free Medium, Cell Transplant. 17 (2008) 1221-1230. https://doi.org/10.3727/096368908787236666.

[271] M.B. Herrera, S. Bruno, S. Buttiglieri, C. Tetta, S. Gatti, M.C. Deregibus, B. Bussolati, G. Camussi, Isolation and Characterization of a Stem Cell Population from Adult Human Liver, Stem Cells. 24 (2006) 2840-2850. https://doi.org/10.1634/stemcells.2006-0114.

[272] J. Kon, N. Ichinohe, H. Ooe, Q. Chen, K. Sasaki, T. Mitaka, Thy1-positive cells have bipotential ability to differentiate into hepatocytes and biliary epithelial cells in galactosamine-induced rat liver regeneration., Am. J. Pathol. 175 (2009) 2362-71. https://doi.org/10.2353/ajpath.2009.080338.

[273] B.E. Petersen, J.P. Goff, J.S. Greenberger, G.K. Michalopoulos, Hepatic oval cells express the 
hematopoietic stem cell marker thy-1 in the rat, Hepatology. 27 (1998) 433-445. https://doi.org/10.1002/hep.510270218.

[274] C. Rauch, Alternatives to the use of fetal bovine serum: human platelet lysates as a serum substitute in cell culture media, ALTEX. 28 (2011) 305-316. https://doi.org/10.14573/altex.2011.4.305.

[275] J. van der Valk, K. Bieback, C. Buta, B. Cochrane, W.G. Dirks, J. Fu, J.J. Hickman, C. Hohensee, R. Kolar, M. Liebsch, F. Pistollato, M. Schulz, D. Thieme, T. Weber, J. Wiest, S. Winkler, G. Gstraunthaler, Fetal bovine serum (FBS): Past - present - future, ALTEX. 35 (2018) 99-118. https://doi.org/10.14573/altex.1705101.

[276] M. Auber, D. Fröhlich, O. Drechsel, E. Karaulanov, E.-M. Krämer-Albers, Serum-free media supplements carry miRNAs that co-purify with extracellular vesicles., J. Extracell. Vesicles. 8 (2019) 1656042. https://doi.org/10.1080/20013078.2019.1656042.

[277] J. Frank, M. Richter, C. de Rossi, C.-M. Lehr, K. Fuhrmann, G. Fuhrmann, Extracellular vesicles protect glucuronidase model enzymes during freeze-drying., Sci. Rep. 8 (2018) 12377. https://doi.org/10.1038/s41598-018-30786-y.

[278] M. Richter, K. Fuhrmann, G. Fuhrmann, Evaluation of the Storage Stability of Extracellular Vesicles, J. Vis. Exp. (2019) e59584. https://doi.org/10.3791/59584.

[279] E. Schulz, A. Goes, R. Garcia, F. Panter, M. Koch, R. Müller, K. Fuhrmann, G. Fuhrmann, Biocompatible bacteria-derived vesicles show inherent antimicrobial activity, J. Control. Release. 290 (2018) 46-55. https://doi.org/10.1016/j.jconrel.2018.09.030.

[280] J. Lötvall, A.F. Hill, F. Hochberg, E.I. Buzás, D. Di Vizio, C. Gardiner, Y.S. Gho, I. V Kurochkin, S. Mathivanan, P. Quesenberry, S. Sahoo, H. Tahara, M.H. Wauben, K.W. Witwer, C. Théry, Minimal experimental requirements for definition of extracellular vesicles and their functions: a position statement from the International Society for Extracellular Vesicles., J. Extracell. Vesicles. 3 (2014) 26913. https://doi.org/10.3402/jev.v3.26913.

[281] A.E. Russell, A. Sneider, K.W. Witwer, P. Bergese, S.N. Bhattacharyya, A. Cocks, E. Cocucci, U. Erdbrügger, J.M. Falcon-Perez, D.W. Freeman, T.M. Gallagher, S. Hu, Y. Huang, S.M. Jay, S. Kano, G. Lavieu, A. Leszczynska, A.M. Llorente, Q. Lu, V. Mahairaki, D.C. Muth, N. Noren Hooten, M. Ostrowski, I. Prada, S. Sahoo, T.H. Schøyen, L. Sheng, D. Tesch, G. Van Niel, R.E. Vandenbroucke, F.J. Verweij, A. V. Villar, M. Wauben, A.M. Wehman, H. Yin, D.R.F. Carter, P. Vader, Biological membranes in EV biogenesis, stability, uptake, and cargo transfer: an ISEV position paper arising from the ISEV membranes and EVs workshop, J. Extracell. Vesicles. 8 (2019) 1684862. https://doi.org/10.1080/20013078.2019.1684862.

[282] R.E. Schwartz, H.E. Fleming, S.R. Khetani, S.N. Bhatia, Pluripotent stem cell-derived hepatocyte-like cells, Biotechnol. Adv. 32 (2014) 504-513. https://doi.org/10.1016/J.BIOTECHADV.2014.01.003.

[283] J. Christoffersson, C. Aronsson, M. Jury, R. Selegård, D. Aili, C.-F. Mandenius, Fabrication of modular hyaluronan-PEG hydrogels to support 3D cultures of hepatocytes in a perfused liveron-a-chip device, Biofabrication. 11 (2018) 015013. https://doi.org/10.1088/1758-5090/aaf657.

[284] Z. Heidariyan, M.H. Ghanian, M. Ashjari, Z. Farzaneh, M. NajarasI, M. Rezaei Larijani, A. Piryaei, M. Vosough, H. Baharvand, Efficient and cost-effective generation of hepatocyte-like 
cells through microparticle-mediated delivery of growth factors in a 3D culture of human pluripotent stem cells, Biomaterials. 159 (2018) 174-188.

https://doi.org/10.1016/J.BIOMATERIALS.2018.01.005.

[285] D. Povero, E.M. Pinatel, A. Leszczynska, N.P. Goyal, T. Nishio, J. Kim, D. Kneiber, L. de Araujo Horcel, A. Eguchi, P.M. Ordonez, T. Kisseleva, A.E. Feldstein, Human induced pluripotent stem cell-derived extracellular vesicles reduce hepatic stellate cell activation and liver fibrosis, JCI Insight. 4 (2019). https://doi.org/10.1172/jci.insight.125652. 